\title{
Differential Tonic GABA Conductances in Striatal Medium Spiny Neurons
}

\author{
Kristen K. Ade, ${ }^{1,2}$ Megan J. Janssen, ${ }^{1,3}$ Pavel I. Ortinski, ${ }^{1,2,4}$ and Stefano Vicini1 ${ }^{1,2}$ \\ ${ }^{1}$ Department of Physiology and Biophysics, ${ }^{2}$ Interdisciplinary Program in Neuroscience, and ${ }^{3}$ Department of Pharmacology, Georgetown University School \\ of Medicine, Washington, DC 20007, and 4Division of Neurology, The Children's Hospital of Philadelphia, Abramson Research Center, Philadelphia, \\ Pennsylvania 19104-4318
}

\begin{abstract}
Medium spiny neurons (MSNs) provide the principal output for the dorsal striatum. Those that express dopamine $\mathrm{D}_{2}$ receptors $\left(\mathrm{D}_{2}{ }^{+}\right)$ project to the globus pallidus external and are thought to inhibit movement, whereas those that express dopamine $\mathrm{D}_{1}$ receptors $\left(\mathrm{D}_{1}{ }^{+}\right)$ project to the substantia nigra pars reticulata and are thought to facilitate movement. Whole-cell and outside-out patch recordings in slices from bacterial artificial chromosome transgenic mice examined the role of $\mathrm{GABA}_{\mathrm{A}}$ receptor-mediated currents in dopamine receptor $\mathrm{D}_{1}{ }^{+}$striatonigral and $\mathrm{D}_{2}{ }^{+}$striatopallidal MSNs. Although inhibitory synaptic currents were similar between the two neuronal populations, $\mathrm{D}_{2}{ }^{+}$MSNs showed greater $\mathrm{GABA}_{\mathrm{A}}$ receptor-mediated tonic currents. TTX application abolished the tonic current to a similar extent as $\mathrm{GABA}_{\mathrm{A}}$ antagonists, suggesting a synaptic origin of the ambient GABA. Low GABA concentrations produced larger whole-cell responses and longer GABA channel openings in $\mathrm{D}_{2}{ }^{+}$than in $\mathrm{D}_{1}{ }^{+}$MSNs. Recordings from MSNs in $\alpha 1^{-/-}$mice and pharmacological analysis of tonic currents suggested greater expression of $\alpha 5$-containing $\mathrm{GABA}_{\mathrm{A}}$ receptors in $\mathrm{D}_{2}{ }^{+}$than in $\mathrm{D}_{1}{ }^{+} \mathrm{MSNs}^{-}$As a number of disorders such as Parkinson's disease, Huntington's chorea, and tardive dyskinesia arise from an imbalance between these two pathways, the $\mathrm{GABA}_{\mathrm{A}}$ receptors responsible for tonic currents in $\mathrm{D}_{2}{ }^{+} \mathrm{MSN}$ may be a potential target for therapeutic intervention.
\end{abstract}

Key words: $\mathrm{GABA}_{\mathrm{A}}$ receptors; tonic inhibition; striatum; medium spiny neurons; patch-clamp; chloride channel

\section{Introduction}

The dorsal striatum (caudate/putamen in primates) is a major nucleus of the basal ganglia and plays a role in motor behavior and habit learning (Graybiel, 2005). Striatal cells receive convergent glutamatergic afferents from the cortex and thalamus, dopaminergic afferents from the substantia nigra pars compacta (SNpc) (Graybiel, 2005), and are intrinsically innervated by striatal GABAergic and cholinergic interneurons (Tepper et al., 2004). Ninety-five percent of striatal cells are GABAergic projections called medium spiny neurons. They are indistinguishable in somatic size and basic physiological properties (Venance and Glowinski, 2003) and belong to one of two pathways. Striatopallidal medium spiny neurons (MSNs) of the "indirect pathway" expresses dopamine $\mathrm{D}_{2}$ receptors $\left(\mathrm{D}_{2}{ }^{+}\right)$and inhibit movement, whereas striatonigral MSNs of the "direct pathway" express dopamine $\mathrm{D}_{1}$ receptors $\left(\mathrm{D}_{1}{ }^{+}\right)$, and facilitate movement (Gerfen et al., 1990). Parkinson's disease, a debilitating neurodegenerative disorder characterized by impaired initiation of movement, is caused by a loss of dopaminergic cells in the SNpc (Alexi et al.,

Received Aug. 27, 2007; revised Nov. 19, 2007; accepted Dec. 12, 2007.

This work was supported by National Institutes of Health Grant R01 MH64797. We thank Dr. David Lovinger at the National Institute on Alcoholism and Alcohol Abuse for providing the BACD and $D_{1}$ EGFP mice, Dr. Gregg Homanics at University of Pittsburgh for providing the $\alpha 1^{-1-}$ mice, and Dr. Jean Marc Fritschy at the University of Zurich for providing the antibodies.

Correspondence should be addressed to Kristen K. Ade, Department of Physiology and Biophysics, BSB230, Georgetown University School of Medicine, 3900 Reservoir Road, Washington, DC 20007. E-mail: kka5@georgetown.edu.

D01:10.1523/JNEUROSCI.3908-07.2008

Copyright $\odot 2008$ Society for Neuroscience $\quad$ 0270-6474/08/281185-13\$15.00/0
2000), leading to increased cell excitability and inhibitory output of the striatopallidal MSNs (Filion and Tremblay, 1991; Raz et al., 2000). This effect has been linked to changes in GABAergic control of MSN action potential firing (Mallet et al., 2006).

GABA is the main inhibitory neurotransmitter in the CNS. $\mathrm{GABA}_{\mathrm{A}}$ receptors are pentamers comprising distinct subunits $(\alpha 1-\alpha 6, \beta 1-\beta 3, \gamma 1-\gamma 3, \delta, \varepsilon, \theta 1-\theta 3, \pi$, and $\rho 1-\rho 3)$ and form a ligand-gated ion pore that is permeable to $\mathrm{Cl}^{-}$and $\mathrm{HCO}_{3}^{-}$(MacDonald and Olsen, 1994). The specific subunit composition of the receptors determines the channel kinetics, pharmacological sensitivity (MacDonald and Olsen, 1994; Vicini and Ortinski, 2004), and subcellular localization (Fritschy and Brunig, 2004; Lüscher and Keller, 2004). Synaptic $\mathrm{GABA}_{\mathrm{A}}$ receptors have a relatively low affinity for GABA (Macdonald and Olsen, 1994; Stell and Mody, 2002). They mediate phasic inhibition in which quantal release of GABA from a presynaptic neuron induces a distinct high-amplitude, rapidly decaying, generally hyperpolarizing event in the postsynaptic neuron (Koos et al., 2004) and play an important role in temporally regulating spike timing (Pouille and Scanziani, 2001; Tepper et al., 2004).

However, low concentrations of GABA can also generate tonic inhibitory currents at high-affinity extrasynaptic $\mathrm{GABA}_{\mathrm{A}}$ receptors. These currents usually have lower amplitudes and longer decay times than synaptic receptors and show little or no desensitization (Farrant and Nusser, 2005). The biophysical properties of tonic receptors provide a cell with a powerful persistent inhibition that allows for regulation of network excitability and in- 
formation processing (Semyanov et al., 2003; Scimemi et al., 2005).

In this study, we provide evidence that MSNs contain $\mathrm{GABA}_{\mathrm{A}}$ receptors that can mediate inhibitory tonic currents. We demonstrate that the $\mathrm{D}_{2}{ }^{+}$MSNs show larger tonic inhibitory currents and a higher sensitivity to low concentrations of GABA than the $\mathrm{D}_{1}{ }^{+}$MSNs, which is likely attributable to greater expression of $\alpha 5$-subunit-containing $\mathrm{GABA}_{\mathrm{A}}$ receptors in $\mathrm{D}_{2}{ }^{+}$MSNs. Furthermore, we show that these tonic currents play an important role in regulating MSN excitability and thus may be a potential target to pharmacologically regulate the imbalance in striatal output underlying the symptoms of Parkinson's disease.

\section{Materials and Methods}

Animals. Bacterial artificial chromosome (BAC) $\mathrm{D}_{2}$ enhanced green fluorescent protein (EGFP) and BAC $D_{1}$ EGFP mice (Gong et al., 2003) (provided by David Lovinger National Institute on Alcoholism and Alcohol Abuse, Bethesda, MD) were crossed with C57BL/6 mice. $\alpha 1$ subunit-deficient mice were described by Vicini et al. (2001) and genotyped with PCR as described by Ortinski et al. (2004). Slices were prepared from postnatal day 16-25 male and female mice.

When BAC $D_{2}$ EGFP mice were used, MSNs were classified as being either dopamine $\mathrm{D}_{2}$ receptor positive or negative by their expression of EGFP. Because previous studies have demonstrated that MSNs express either dopamine $\mathrm{D}_{1}$ or $\mathrm{D}_{2}$ receptors (Gerfen et al., 1990; Day et al., 2006), all MSNs negative for EGFP in the BAC $D_{2}$ EGFP mice were presumed to be $\mathrm{D}_{1}{ }^{+}$and will hereafter be referred to as such. To verify that the results obtained were not attributable to EGFP expression or the specific mouse model, some experiments were repeated in the BAC $\mathrm{D}_{1}$ EGFP mice. In these experiments, $\mathrm{D}_{1}{ }^{+}$MSNs were identified by EGFP expression, and those that were negative for EGFP were presumed to be $\mathrm{D}_{2}{ }^{+}$. Because there were no differences observed between the two strains of mice, data were pooled and all MSNs are defined as either $\mathrm{D}_{1}{ }^{+}$or $\mathrm{D}_{2}{ }^{+}$.

Slice preparation. Mice were killed by decapitation in agreement with the guidelines of the American Veterinary Medical Association Panel on Euthanasia and the Georgetown University Animal Care and Use Committee. The whole brain was removed and placed in an ice-cold slicing solution containing the following (in $\mathrm{mM}$ ): $85.0 \mathrm{NaCl}, 2.5 \mathrm{KCl}, 1.0 \mathrm{CaCl}_{2}$, $4.0 \mathrm{MgCl}_{2}, 1.0 \mathrm{NaH}_{2} \mathrm{PO}_{4}, 25.0 \mathrm{NaHCO}_{3}, 25.0$ glucose, and 75.0 sucrose. Corticostriatal coronal slices, $250 \mu \mathrm{m}$, were prepared using a Vibratome 3000 Plus Sectioning System (Vibratome, St. Louis, MO) and were incubated in the slicing solution at $32^{\circ} \mathrm{C}$ for $30 \mathrm{~min}$. Slices then recovered for $30 \mathrm{~min}$ at $32^{\circ} \mathrm{C}$ in artificial CSF (aCSF) containing the following (in $\mathrm{mm}$ ): 124.0 NaCl, $4.5 \mathrm{KCl}, 1.2 \mathrm{NaH}_{2} \mathrm{PO}_{4}, 26.0 \mathrm{NaHCO}_{3}, 2.0 \mathrm{CaCl}_{2}, 1.0 \mathrm{MgCl}_{2}$, and 10.0 D-glucose (all from Sigma, St. Louis, MO). During experiments, slices were submerged and continuously perfused $(2-3 \mathrm{ml} / \mathrm{min}$ ) with aCSF at room temperature $22-24^{\circ} \mathrm{C}$ or $31^{\circ} \mathrm{C}$ when indicated. Slice temperature was maintained with an inline heater (TC-324B; Warner Instruments, Hamden, CT) and continuously monitored with a submerged miniature thermistor probe situated within the recording chamber adjacent to the slice. All solutions were maintained at $\mathrm{pH} 7.4$ by continuous bubbling with $95 \% \mathrm{O}_{2} / 5 \% \mathrm{CO}_{2}$.

Slices were visualized under an upright microscope (E600FN; Nikon, Tokyo, Japan) equipped with Nomarski optics and an electrically insulated $60 \times$ water immersion objective with a long working distance $(2$ $\mathrm{mm}$ ) and high numerical aperture (1.0). Recording electrodes were pulled on a vertical pipette puller from borosilicate glass capillaries (Wiretrol II; Drummond, Broomall, PA) and filled with KCl-based internal recording solution ( $\mathrm{KCl}$ internal) containing the following (in mM): $145 \mathrm{KCl}, 10$ HEPES, 5 ATP.Mg, 0.2 GTP-Na, and 10 EGTA, adjusted to $\mathrm{pH} 7.2$ with $\mathrm{KOH}$. Alternatively, for K-gluconate-based internal solutions (K-gluconate internal), $\mathrm{KCl}$ was replaced with equimolar $\mathrm{K}$-gluconate. In CsCl-based internal solutions ( $\mathrm{CsCl}$ internal), $\mathrm{KCl}$ was replaced with equimolar $\mathrm{CsCl}$, and, in this case, $\mathrm{pH}$ was adjusted with $\mathrm{CsOH}$.

Whole-cell recordings. Voltage-clamp recordings were performed using whole-cell configuration of the patch-clamp technique at a pipette voltage of $-60 \mathrm{mV}$ using the Axopatch 200B amplifier (Molecular De- vice, Sunnyvale, CA). Access resistance was monitored throughout the recordings, and experiments with $>20 \%$ change were discarded. When potassium-based internal solutions were used, depolarizing current injections were given in current-clamp configuration, and only cells that showed the typical response for MSNs (see Results) were used in the analysis. Before each series of current step injection protocols, cells were brought back to $-65 \mathrm{mV}$ when $\mathrm{K}$-gluconate internal was used and -70 $\mathrm{mV}$ when $\mathrm{KCl}$ internal was used. Responses to two repeated series of current injections were averaged for all firing frequency and input resistance data.

Stock solutions of bicuculline methobromide (BIC), 1-[2([(diphenylmethylene) imino]oxy)ethyl]-1,2,5,6-tetrahydro-3-pyridinecarboxylic acid hydrochloride (NO711), SR95531 [gabazine (GBZ)], strychnine, tetrodotoxin (TTX), 4,5,6,7-tetrahydroisoxazolo $\{5,4-\mathrm{c}\}$ pyridine-3-ol (THIP), and GABA (all from Sigma) and sodium-2,3-dihydro-6-nitro-7sulfamoyl-benzo[f]quinoxaline (NBQX) (Tocris Bioscience, Ellisville, MO), were prepared in water. Zolpidem and L655,708 (Tocris Bioscience) were dissolved in dimethylsulfoxide ( $<0.0001 \%$ final concentration). All stock solutions were then diluted to the desired concentration in the aCSF and were applied locally through a Y tube (Murase et al., 1989) modified for optimal solution exchange in brain slices (Hevers and Luddens, 2002) except when noted.

Currents were filtered at $2 \mathrm{kHz}$ with a low-pass Bessel filter and digitized at 5-10 kHz (for whole cells) and $20 \mathrm{kHz}$ (for single channels) using a personal computer equipped with Digidata 1322A data acquisition board and pClamp9 software (both from Molecular Devices). Off-line data analysis, curve fitting, and figure preparation were performed with Clampfit 9 software (Molecular Devices). Spontaneous and miniature IPSCs (sIPSCs and mIPSCs) were identified using a semiautomated threshold based mini detection software [Mini Analysis; Synaptosoft, Fort Lee, NJ (www.synaptosoft.com)] and were visually confirmed. Event detection threshold was set at five times the root mean square level of baseline noise. IPSC averages were based on $>60$ events in each cell studied, and the decay kinetics were determined using single-exponential curve fitting and reported as weighted time constants (tau) as in the study by Vicini et al. (2001). NBQX was not included in sIPSC measurements so as not to perturb the network activity. However, AMPA-mediated mEPSCs, although infrequent, could easily be identified by the rapid decay kinetics $(<2 \mathrm{~ms})$ as in the study by Ortinski et al. (2004) and were excluded from the analysis. mIPSCs were isolated by application of TTX $(0.5 \mu \mathrm{M})$, NBQX $(5 \mu \mathrm{M})$, and strychnine $(0.5 \mu \mathrm{M})$. All detected events were used for event frequency analysis, but superimposing events were eliminated for the amplitude, rise time, and decay kinetic analysis. For tonic current measurements, an all-points histogram was plotted for a $10 \mathrm{~s}$ period immediately preceding drug application. A Gaussian was fitted to the side of the distribution not skewed by synaptic events, and the peak was used to determine the mean baseline holding current required to maintain the voltage of the cell at $-60 \mathrm{mV}$. Tonic currents blocked or induced by various pharmacological agents are represented as absolute magnitude and were determined by repeating the fitting procedure for the $10 \mathrm{~s}$ immediately after drug application and calculating the $\Delta$ for the peak of the Gaussians.

Dose-response curves were fitted using Origin (Microcal, Northampton, MA) with the logistic function $I_{\text {peak }}=I_{\min }+\left(I_{\max }-I_{\min } / 1+\right.$ ([Drug] $\left.]^{\text {slope }} / \mathrm{EC}_{50}\right)$ ), where $I_{\min }$ and $I_{\max }$ are minimal and maximal evoked currents, [Drug] is GABA or THIP concentration, and slope is slope of the curve. Capacitance of MSNs in slice cannot be accurately measured as a result of their extensive dendritic arborization. Therefore, whole-cell currents induced by application of THIP are normalized to the whole-cell current evoked by a saturating dose of GABA in the same cell.

Excised patch recordings. Recordings of single-channel activity were performed in excised outside-out patches held at $-60,-80$, or -100 $\mathrm{mV}$. Because it was rare to find patches with single channels, kinetic analyses were performed on stretches with few superimposed channel openings as in the study by Barberis et al. (2007). Events for singlechannel dwell time analyses were collected using half-amplitude threshold detection method built into Clampfit 9 software (Molecular Devices), and $>1000$ events were collected for all conditions. Superimposed 
openings were excluded. Logarithmic open interval distributions were binned and fitted with a sum of three logarithmic exponential probability density functions using the maximum likelihood method after taking the square root of the bin counts to improve statistical scatter of the data (Sigworth and Sine, 1987). Mean unitary current was determined from the fits of amplitude distributions of openings lasting $>0.5 \mathrm{~ms}$ with Gaussian components. Single-channel slope conductance was estimated from the linear fit of the $I-V$ relationship at three distinct holding potentials. Only the openings to the main conductance level were considered for the $I-V$ fit. Statistical comparisons were done using a two-tailed Student's $t$ test assuming homogeneity of variances of the samples as verified by an $F$ test.

Resting membrane potential (RMP) was determined from an estimate of the reversal potential for $\mathrm{K}^{+}\left(E_{\mathrm{K}}\right)$ with a series of command voltage ramps given in cell-attached configuration as in the study of Verheugen et al. (1999). Briefly, cell-attached gigaohm seals were made with pipettes that contained $145 \mathrm{~mm} \mathrm{~K}^{+}$. The cell was then subjected to a series of five repeated ramps from -100 to $+200 \mathrm{mV}$. Because the intracellular solution contained an isotonic concentration of $\mathrm{K}^{+}$, the equilibrium potential for $\mathrm{K}^{+}$was $\sim 0 \mathrm{mV} . \mathrm{K}^{+}$currents were measured, and the holding potential at which the $\mathrm{K}^{+}$currents reversed gave a direct measurement of the resting membrane potential of the cell.

In some experiments, the glutamatergic afferents were stimulated by square-wave $50 \mu$ s electric pulses delivered by a bipolar stimulating electrode placed within the white matter at the corticostriatal border as in the study by Ade and Lovinger (2007) at a frequency of $0.2 \mathrm{~Hz}$. Action potential firing was recorded from single cells in loose cell-attached configuration. The stimulus intensity $(100-300 \mu \mathrm{A})$ was set to evoke action potentials in the recorded cell approximated $50 \%$ of the time during baseline conditions. Firing frequency for each condition was based on $>50$ stimuli.

Statistical significance for all analyses was determined using a twotailed Student's $t$ test (unpaired when comparing two populations of cells and paired when comparing conditions in the same cell population). All data values in the text and in the figures are expressed as mean \pm SEM unless otherwise indicated. For all figures, ${ }^{*} p<0.05,{ }^{* *} p<0.005$, and ${ }^{* * *} p<0.0005$.

Immunofluorescence. Animals were anesthetized with isofluorane and perfused transcardially with $1 \times$ PBS followed by $4 \%$ paraformaldehyde in $1 \times$ PBS $(100 \mathrm{ml})$. The whole brains were then immersed in the same fixative solution at $4^{\circ} \mathrm{C}$ for $1-3 \mathrm{~h}$ and then transferred to $30 \%$ sucrose in PBS and left at $4^{\circ} \mathrm{C}$ until the slicing procedure. Fifty-micrometer-thick coronal and longitudinal slices were cut in PBS using a Lancer Vibratome Series 1000 Sectioning System, and subsequent immunofluorescent processing was performed on the free-floating sections. Briefly, slices were incubated in primary antibody overnight in blocking solution $(5 \%$ bovine serum albumin in $1 \times$ TBS with $0.05 \%$ Triton X-100) at $4^{\circ} \mathrm{C}$. Slices were subsequently rinsed three times for $20 \mathrm{~min}$ in $1 \times \mathrm{TBS}$ at room temperature and were then incubated in fluorescent secondary antibody probes in the same blocking solution at $4^{\circ} \mathrm{C}$ for $2 \mathrm{~h}$. Slices were then subjected to the same rinsing procedure and were mounted in Vectashield Mounting Medium (Vector Laboratories, Burlingame, CA). All incubation and rinsing steps were performed with gentle agitation.

Antibodies raised in guinea pig against the $\alpha 5$ subunit (1:3000 final concentration) and the $\alpha 2$ subunit (1:5000 final concentration), kind gifts from Dr. Jean Marc Fritschy (University of Zurich, Zurich, Switzerland), were used as primary antibodies. Indocarbocyanine-conjugated secondary antibodies were from Jackson ImmunoResearch (West Grove, PA) and were used at 1:1000 final concentration.

Images were captured with confocal laser scanning microscopy (Fluoview-FV300 Laser Scanning Confocal System; Olympus Optical, Tokyo, Japan) with a $100 \times$ Plan-Acromat objective (numerical aperture 1.4) and sequential acquisition of separate color channels. Stacks of eight consecutive sections $(512 \times 512)$ spaced by $0.3 \mu \mathrm{m}$ were analyzed with MetaMorph (Universal Imaging, Downingtown, PA) and pseudocolored for presentation with Adobe Photoshop CS2 (Adobe Systems, San Jose, CA). To quantify changes in fluorescence intensity, we measured the number of clusters and their average pixel intensity of several region of interest defined from the location of MSNs as seen in matching Nomarski
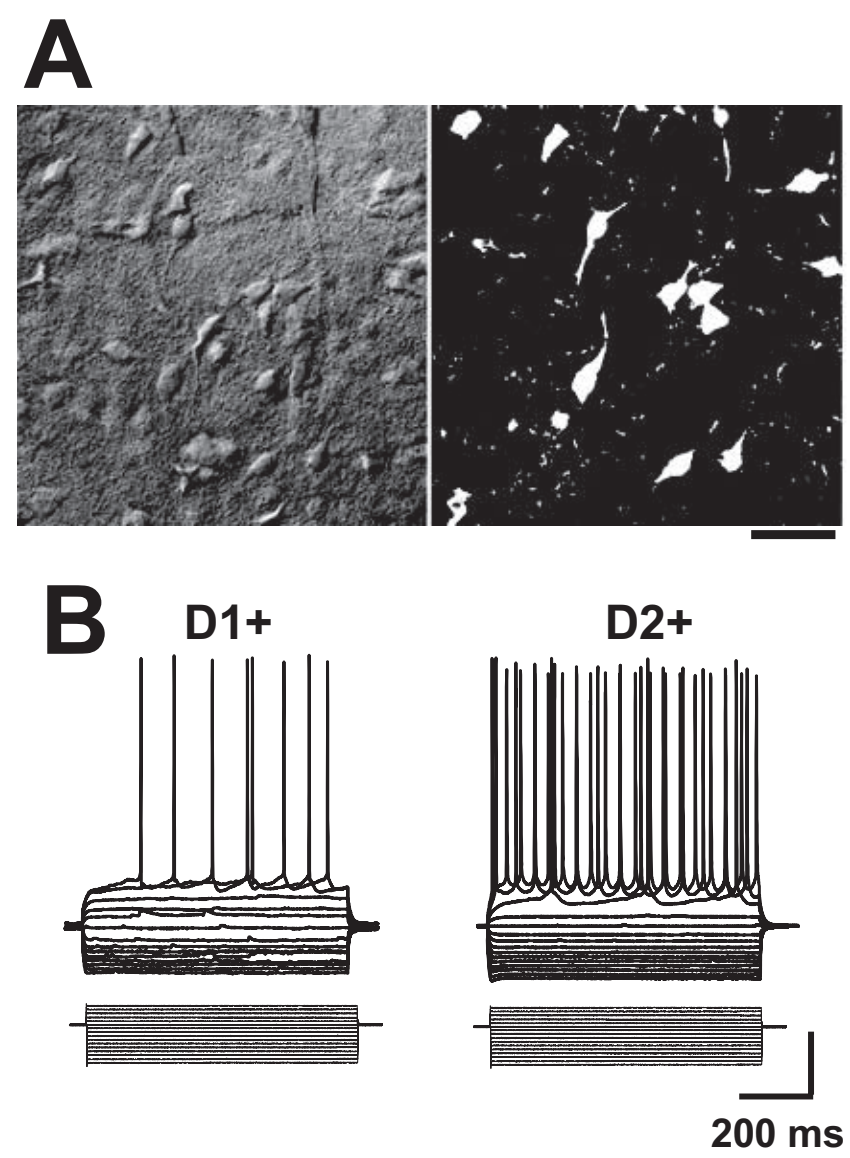

Figure 1. Characteristics of $\mathrm{D}_{1}{ }^{+}$and $\mathrm{D}_{2}{ }^{+}$medium spiny neurons. $A$, Examples of differential interference contrast (left) and fluorescence (right) confocal micrographs of a corticostriatal slice prepared from a BACD ${ }_{2}$ EGFP mouse. EGFP expression was used to classify MSNs as $\mathrm{D}_{1}{ }^{+}$or $\mathrm{D}_{2}{ }^{+}$. Scale bar, $20 \mu \mathrm{m}$. $\boldsymbol{B}$, Examples of current-clamp recordings with K-gluconate internal, demonstrating responses to a series of hyperpolarizing and depolarizing current injections (20 pA steps) from RMPs of $-65 \mathrm{mV}$ in a $\mathrm{D}_{1}{ }^{+}$and $\mathrm{D}_{2}{ }^{+} \mathrm{MSN}$. Calibration: $20 \mathrm{mV}, 100 \mathrm{pA}$.

images (supplemental Fig. S2, available at www.jneurosci.org as supplemental material). Individual clusters were identified by threshold segmentation. No staining was observed in areas in which including the white matter or in control sections in which the primary antibody was omitted. Quantification analysis was performed in at least 30 cells per group from three separate sections in two mice, and data are expressed as mean \pm SEM. $p$ values represent the results of two-tailed unpaired Student's $t$ tests.

\section{Results}

To compare inhibitory currents in striatopallidal and striatonigral MSNs, recordings were routinely performed in acute corticostriatal slices prepared from BAC transgenic mice in which EGFP expression is driven by the promoter for the dopamine $\mathrm{D}_{2}$ receptor (Fig. $1 A, B$ ). Striatal cells were identified as being either dopamine $\mathrm{D}_{2}$ receptor positive $\left(\mathrm{D}_{2}{ }^{+}\right)$or negative (presumed $\mathrm{D}_{1}{ }^{+}$; see Materials and Methods) by the expression of EGFP.

During whole-cell recordings, striatal cells were subjected to a series of hyperpolarizing and depolarizing current injections (Fig. $1 B$ ), and MSNs were identified by their characteristic repetitive and non-adapting firing pattern, which lacks an afterhyperpolarization (Kita et al., 1984; Kawaguchi et al., 1989). We found that all EGFP-positive striatal cells recorded from in slices from BAC $\mathrm{D}_{2}$ EGFP mice demonstrated characteristics typical of MSNs $(n>100)$. On the surface, these results would appear to 
contradict a recent report that the cholinergic interneurons in the striatum express dopamine $\mathrm{D}_{2}$ receptors and thus should be EGFP positive in this strain of mice (Wang et al., 2006). However, the somatic size of these interneurons is approximately two to three times larger than the typical MSN (Kawaguchi et al., 1995) and thus could easily be avoided for the purpose of this study.

In contrast, $\sim 3-5 \%$ of striatal cells negative for EGFP demonstrated firing patterns suggestive of an interneuron phenotype and were thus excluded from the analysis. These findings agree with both a previous report (Le Moine et al., 1991) and with unpublished data from our laboratory in which immunolabeling for striatal GABAergic interneuron markers did not overlap with EGFP expression in slices from these mice. Because action potential firing patterns could not be studied when $\mathrm{CsCl}$ internal was used, a small amount of data analysis on inhibitory currents in $\mathrm{D}_{1}{ }^{+}$MSNs may have been derived from GABAergic interneurons when using this internal solution.

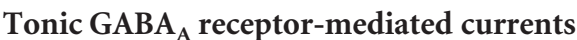

When potassium-based isotonic chloride internal solution $(\mathrm{KCl}$ internal) was used for voltage-clamp recordings, application of the $\mathrm{GABA}_{\mathrm{A}}$ receptor antagonist $\mathrm{BIC}$, in addition to blocking sIPSCs, consistently induced an outward current in $\mathrm{D}_{2}{ }^{+}$MSNs $(18.9 \pm 0.3 \mathrm{pA}, n=40)$ (Fig. 2), revealing an endogenous $\mathrm{GABA}_{\mathrm{A}}$ receptor-mediated tonic current. This effect could also be observed in $\mathrm{D}_{1}{ }^{+}$MSNs, although the magnitude was significantly smaller $(1.7 \pm 0.8 \mathrm{pA}, n=23)$, and often it was completely absent (Fig. 2A-C). The remaining sEPSCs could be blocked by the subsequent application of the AMPA/kainate receptor antagonist NBQX (Fig. 2A,B). Because BIC has also been shown to block nicotinic acetylcholine receptors (Rossi et al., 2003) and $\mathrm{Ca}^{2+}$ gated $\mathrm{K}^{+}$channels (Johnson and Seutin, 1997), we confirmed that the tonic current was indeed mediated by $\mathrm{GABA}_{\mathrm{A}}$ receptors by repeating these experiments with a more specific $\mathrm{GABA}_{\mathrm{A}}$ receptor antagonist, gabazine ( $10 \mu \mathrm{M}, \mathrm{KCl}$ internal), which blocked significantly more tonic current in $\mathrm{D}_{2}{ }^{+}$MSNs $(16.0 \pm 1.2 \mathrm{pA}$, $n=8)$ than in $\mathrm{D}_{1}{ }^{+}$MSNs $(3.0 \pm 1.7 \mathrm{pA}, n=5)(p<0.01)$. Subsequent BIC application caused no additional effects (data not shown), nor did the values obtained with GBZ significantly differ from those previous experiments performed with BIC, suggesting that the blockade of tonic current by BIC was a result of antagonizing the $\mathrm{GABA}_{\mathrm{A}}$ receptor rather than modulation of non-GABA ${ }_{A}$ receptor-mediated conductances. The difference in GABA tonic currents (determined by application of either BIC or GBZ with $\mathrm{KCl}$ internal solution) was seen at higher temperatures $\left(31^{\circ} \mathrm{C}\right)$ as well $\left(\mathrm{D}_{1}{ }^{+} \mathrm{MSNs}, 1.6 \pm 1.3 \mathrm{pA}, n=5 ; \mathrm{D}_{2}{ }^{+} \mathrm{MSNs}\right.$, $30.4 \pm 5.5 \mathrm{pA}, n=5 ; p<0.0005)$.

Although these initial experiments suggested that $\mathrm{D}_{2}{ }^{+}$MSNs exhibit more $\mathrm{GABA}_{\mathrm{A}}$ receptor-mediated tonic current, interpretations were limited to those currents that could be detected by the somatically located recording electrode. It has been suggested that dendritic excitatory synaptic currents in MSNs likely go undetected in whole-cell recordings when potassium-based internal solutions are used because of leak $\mathrm{K}^{+}$currents between the synapse and the soma (Day et al., 2006). Although low input resistance of the membrane distorts fast synaptic events more than steady- state currents, the magnitude of constant currents at more distal dendritic regions may be attenuated by low input resistance of the dendritic plasma membrane (Spruston et al., 1993). Because the input resistance of the MSN dendritic arborization is unknown and cannot be measured in the slice preparation, we could not rule out the possibility that $\mathrm{D}_{1}{ }^{+}$MSNs are influenced by GABA tonic currents at more distal regions of the
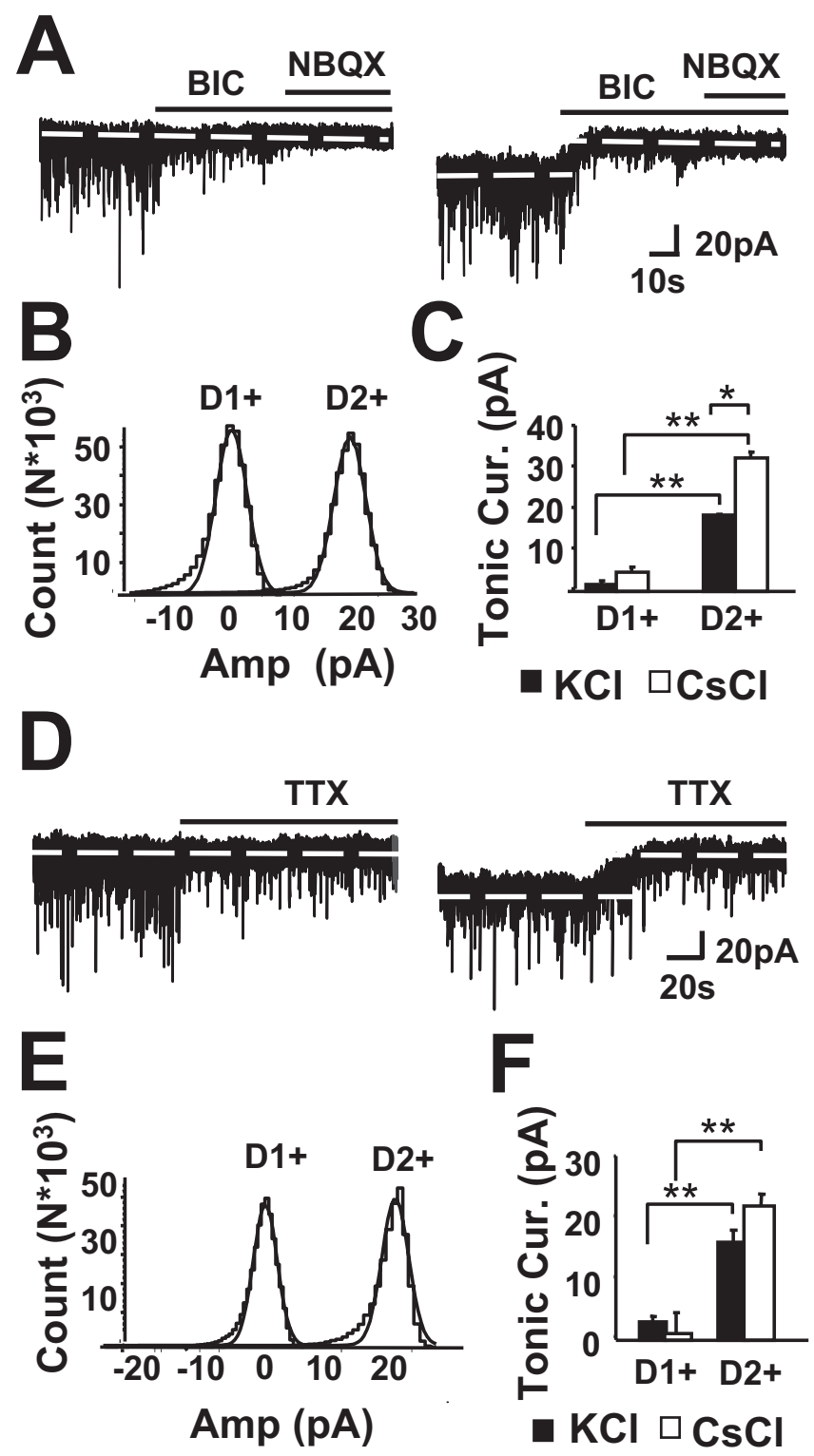

Figure 2. $D_{2}{ }^{+}$MSNs demonstrate larger $G_{A B A}$ receptor-mediated tonic currents than $\mathrm{D}_{1}{ }^{+}$MSNs. $A$, Representative traces from a $\mathrm{D}_{1}{ }^{+}$MSN (left) and a $\mathrm{D}_{2}{ }^{+}$MSN (right) demonstrate that BIC $(25 \mu \mathrm{m})$ blocked sIPSCs in both cell types but only revealed an endogenous GABA-mediated tonic current in the $\mathrm{D}_{2}{ }^{+} \mathrm{MSN}$. The remaining sEPSCs in both cell types were blocked by NBQX (5 $\mu \mathrm{m})$ with no effects on the tonic current. $\boldsymbol{B}$, The mean of the baseline current during BIC application from the representative traces in $\boldsymbol{A}$ were adjusted to 0 , and the amplitude distributions were drawn from segments immediately preceding BIC application. The nonskewed sides of the amplitude histograms were fit with a Gaussian, the peak of which was used to determine the absolute magnitude of tonic current blocked by BIC. C, Summary of tonic currents blocked by BIC ( $25 \mu \mathrm{m}$ ) with $\mathrm{KCl}$ internal (black bars; $n=23$ and 44) and with $\mathrm{CsCl}$ internal (white bars; $n=7$ and 9 ) in $D_{1}{ }^{+}$and $D_{2}{ }^{+}$MSNs, respectively. D, Representative traces from a $\mathrm{D}_{1}{ }^{+}$MSN (left) and a $\mathrm{D}_{2}{ }^{+}$MSN (right) demonstrate that blockade of voltage-gated $\mathrm{Na}^{+}$channels with TTX $(0.5 \mu \mathrm{m})$ reduces the frequency and amplitude of postsynaptic events in both cell types but only alters the amount of holding current required to maintain the holding voltage at $-60 \mathrm{mV}$ in the $\mathrm{D}_{2}{ }^{+}$MSN. $\boldsymbol{E}$, Amplitude distributions representing the tonic current abolished by TTX, drawn from segments in $\boldsymbol{D}$ as described above for BIC $(\boldsymbol{B})$. $\boldsymbol{F}$, Summary of tonic current blocked by $\operatorname{TTX}(0.5 \mu \mathrm{m})$ from recordings with $\mathrm{KCl}$ internal (black bars; $n=11$ and 32) and with $\mathrm{CsCl}$ internal (white bars; $n=6$ and 7 ) in $\mathrm{D}_{1}{ }^{+}$and $\mathrm{D}_{2}{ }^{+} \mathrm{MSN}$, respectively.

dendritic arborization. To address this issue, we used a cesiumbased internal solution ( $\mathrm{CsCl}$ internal) to block $\mathrm{K}^{+}$channels. Under these recording conditions, we detected only a weak BICsensitive tonic current in $\mathrm{D}_{1}{ }^{+}$MSNs $(1.6 \pm 0.3 \mathrm{pA}, n=7)$, 
whereas the tonic current detected in $\mathrm{D}_{2}{ }^{+}$MSNs with $\mathrm{CsCl}$ internal was significantly greater than the tonic current detected with $\mathrm{KCl}$ internal (32.6 $\pm 1.6 \mathrm{pA}, n=9$ ) (Fig. $2 C$ ), suggesting that, in $\mathrm{D}_{2}{ }^{+}$MSNs, GABA onic currents are found in both the soma/perisomatic region as well as the dendrites.

Synaptic spillover from action potential-dependent vesicular release of neurotransmitter is thought to be a primary source for the ambient GABA responsible for activating extrasynaptic tonic $\mathrm{GABA}_{\mathrm{A}}$ receptors (Brickley et al., 1996; Wall and Usowicz, 1997; Bright et al., 2007). In agreement with these findings, application of a sodium channel blocker mimicked the results obtained by BIC application (Fig. 2D-F). TTX $(0.5 \mu \mathrm{M})$ blocked $16.4 \pm 2.8$ $\mathrm{pA}(n=32)$ in $\mathrm{D}_{2}{ }^{+} \mathrm{MSN}$ and $2.9 \pm 0.9 \mathrm{pA}(n=11)$ of tonic current in $\mathrm{D}_{1}{ }^{+}$MSNs with $\mathrm{KCl}$ internal and $22.4 \pm 1.9 \mathrm{pA}(n=$ $6)$ in $\mathrm{D}_{2}{ }^{+}$MSNs and $1.0 \pm 3.1 \mathrm{pA}(n=7)$ in $\mathrm{D}_{1}{ }^{+}$MSNs with $\mathrm{CsCl}$ internal (Fig. $2 \mathrm{E}-H)$. Overall, TTX blocked $91 \pm 6 \%(n=$ 7) of the BIC-sensitive tonic current in the $\mathrm{D}_{2}{ }^{+} \mathrm{MSNs}$ as assessed by subsequent application of BIC. Interestingly, perfusion of NBQX $(5 \mu \mathrm{M})$ before BIC also decreased BIC-sensitive tonic current in $\mathrm{D}_{2}{ }^{+} \mathrm{MSNs}$ by $42 \pm 8 \%,(n=4)$, but there were no effects on the tonic current when NBQX was applied after BIC (Fig. $2 A$ ). These results suggest that NBQX decreases GABA tonic currents by affecting striatal circuitry, consistent with the previously described role for glutamatergic synaptic input in driving the activity of striatal interneurons (Mallet et al., 2005).

Our data suggest that synaptic spillover is the primary source for the ambient GABA responsible for inducing tonic currents in MSNs. However, the activity of the GABA transporters strongly regulates the amount of neurotransmitter that is allowed to spill out of the synaptic cleft and activate extrasynaptic receptors (Mody and Pearce, 2004; Farrant and Nusser, 2005). Indeed, studies on tonic inhibition in other brain regions have demonstrated that the ambient GABA levels are highly regulated by the activity of the GABA transporter GAT-1 (Mody and Pearce, 2004; Richerson, 2004; Ortinski et al., 2006; Park et al., 2006). Furthermore, it has been demonstrated that activity of GAT-1 is regulated by cytosolic $\mathrm{Na}^{+}$gradients (Richerson 2004; Wu et al., 2006). Thus, the effects of TTX could partially be mediated by disruption of GAT-1 activity. Although GAT-1 expression is mostly limited to GABAergic interneurons in the striatum (Augood et al., 1995), the smaller tonic currents seen in the $\mathrm{D}_{1}{ }^{+}$ MSNs could potentially be explained by a more efficacious GABA transport system on the synaptic inputs to $\mathrm{D}_{1}{ }^{+} \mathrm{MSN}$ leading to lower local ambient GABA concentrations. If this was indeed the case, inhibiting GAT-1 should induce significantly larger GABA tonic currents in the $\mathrm{D}_{1}{ }^{+}$MSNs. However, application of the GAT-1 inhibitor NO711 (5 $\mu \mathrm{M})$ increased the BIC-sensitive tonic current in both types of MSNs (supplemental Fig. S1 A, B, available at www.jneurosci.org as supplemental material). Furthermore, $\mathrm{D}_{2}{ }^{+}$MSNs still showed significantly more GABA tonic current after NO711 application $(24.8 \pm 4.1 \mathrm{pA}, n=4)$ than the $\mathrm{D}_{1}{ }^{+}$MSNs $(8.8 \pm 4.3 \mathrm{pA}, n=4)$ (supplemental Fig. S1C, available at www.jneurosci.org as supplemental material). In four $\mathrm{D}_{2}{ }^{+}$MSNs recorded with $\mathrm{CsCl}$ internal solution, GABA tonic current after NO711 application was $27.8 \pm 3.6$ pA.

In agreement with recent findings in the hippocampus (Glykys and Mody, 2007), our results suggest that synaptic activity in the striatum plays a crucial role in setting the tonic currents in $\mathrm{D}_{2}{ }^{+} \mathrm{MSN}$. Thus, it was possible that the $\mathrm{D}_{2}{ }^{+} \mathrm{MSN}$ received more synaptic innervation than the $\mathrm{D}_{1}{ }^{+}$MSNs or that the probability of release or quantal content from the inhibitory synaptic inputs to the two cell types differed. Therefore, we compared the amplitude, frequency, rise time, and tau of the synaptic currents in the $\mathrm{D}_{2}{ }^{+}$and $\mathrm{D}_{1}{ }^{+}$MSNs (Fig. 3) using both $\mathrm{KCl}$ and $\mathrm{CsCl}$ internal solutions. Indeed, $\mathrm{CsCl}$ internal significantly enhanced our detection of mIPSCs in both cell types (Fig. 3I) and sIPSCs in the $\mathrm{D}_{2}{ }^{+}$MSNs (Fig. 3C) and demonstrated significantly larger mIPSC amplitude in the $\mathrm{D}_{1}{ }^{+}$MSNs (Fig. $3 \mathrm{H}$ ) when compared with those results obtained with $\mathrm{KCl}$ internal. Yet importantly, $\mathrm{D}_{1}{ }^{+}$and $\mathrm{D}_{2}{ }^{+}$MSNs did not significantly differ from each other in any of the IPSC parameters measured.

\section{$\mathrm{D}_{2}{ }^{+} \mathrm{MSN}$ are more sensitive to GABA than $\mathrm{D}_{1}{ }^{+}$MSNs}

Altogether, the two MSN subtypes appeared to have similar inhibitory synaptic input and local ambient GABA concentrations. Therefore, we investigated whether the larger tonic current in the $\mathrm{D}_{2}{ }^{+}$MSNs resulted from greater surface expression of $\mathrm{GABA}_{\mathrm{A}}$ receptors or a difference in the properties of these receptors, either of which could render them more sensitive to low concentrations of GABA. For this purpose, we compared whole-cell currents in the two cell types induced by increasing concentrations of GABA (Fig. 4) in the presence of NBQX (5 $\mu \mathrm{M})$ and strychnine $(0.5 \mu \mathrm{M})$ to block AMPA and glycine receptor currents (Jonas et al., 1998), respectively, and TTX $(0.5 \mu \mathrm{M})$ to reduce endogenous levels of ambient GABA from synaptic release (Fig. $2 D-F$ ) and found that they exhibited similar maximal currents in response to saturating doses of GABA (Fig. $4 B$ ). Although anatomical constraints slow down agonist application and limit interpretations of agonist dose-response curves in brain slices, these results suggest that the two MSNs subtypes are similar in the total surface expression of $\mathrm{GABA}_{\mathrm{A}}$ receptors. However, $\mathrm{D}_{2}{ }^{+} \mathrm{MSN}$ demonstrated a remarkably greater sensitivity to low doses of GABA than the $\mathrm{D}_{1}{ }^{+}$MSNs (Fig. 4B,C), which further supports the hypothesis that differences in functional properties of the $\mathrm{GABA}_{\mathrm{A}}$ receptors underlies the differences in GABA tonic current magnitude in MSNs.

\section{Extrasynaptic $\mathrm{GABA}_{\mathrm{A}}$ receptors in MSNs}

Subunit composition of the $\mathrm{GABA}_{\mathrm{A}}$ receptor has been shown to significantly affect channel conductance, open probability, and ligand affinity (Macdonald and Olsen, 1994). It also determines subcellular localization-based subunit-specific interaction with scaffolding proteins and whether the receptor can be affected by posttranslational modifications such as phosphorylation (Fritschy and Brunig, 2004; Lüscher and Keller, 2004). Subunit composition also appears to be specific to both the brain subregion and cellular subtype of the neurons on which they are located. For example, extrasynaptic $\mathrm{GABA}_{\mathrm{A}}$ receptors containing the $\delta$ subunit have been shown to mediate tonic inhibition in cerebellar granule cells (for review, see Farrant and Nusser, 2005), dentate gyrus granule cells (Wei et al., 2003), hippocampal interneurons (Semyanov et al., 2003; Glykys et al., 2007), and thalamocortical projection neurons (Belelli et al., 2005; Cope et al., 2005; Jia et al., 2005; Bright et al., 2007). Although immunohistochemical studies of $\mathrm{GABA}_{\mathrm{A}}$ receptor subunit expression have been limited to the rat, these studies have demonstrated diffuse expression patterns of the $\delta$ subunit in the striatum (Pirker et al., 2000; Schwarzer et al., 2001). Therefore, greater tonic current in the $\mathrm{D}_{2}{ }^{+} \mathrm{MSNs}$ could potentially result from greater expression of $\delta$-subunit-containing $\mathrm{GABA}_{\mathrm{A}}$ receptors, in which case, they should show a higher sensitivity to the $\mathrm{GABA}_{\mathrm{A}}$ receptor agonist THIP (Brown et al., 2002) than the $\mathrm{D}_{1}{ }^{+}$MSNs. THIP is a nonspecific partial agonist at most $\mathrm{GABA}_{\mathrm{A}}$ receptors at high concentrations, but at low concentrations, it is somewhat selective and possesses super-agonist properties at $\mathrm{GABA}_{\mathrm{A}}$ receptors lacking the $\gamma 2$ subunit (Storustovu and Ebert, 2006), a large 


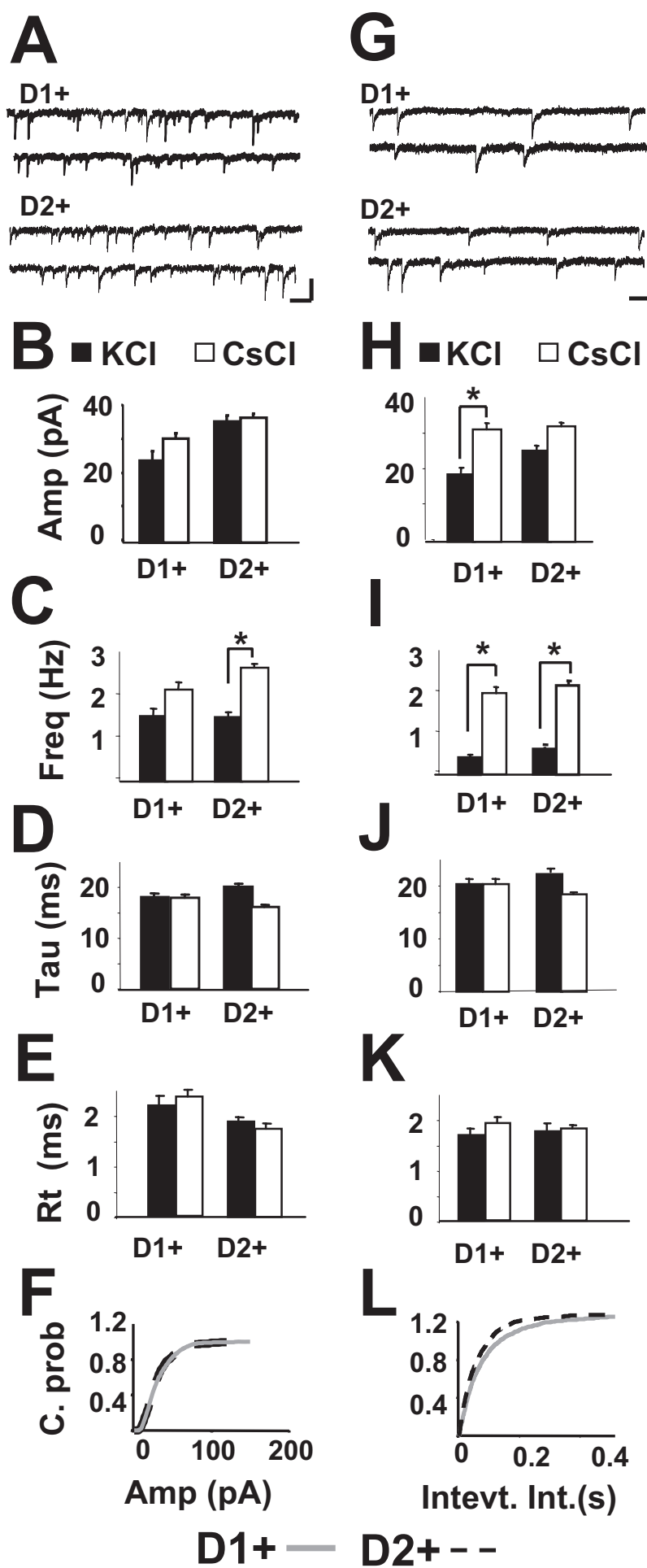

Figure 3. GABA receptor-mediated sIPSCS and mISPCS do not differ between $\mathrm{D}_{1}{ }^{+}$and $\mathrm{D}_{2}{ }^{+}$ MSNs. $A$, Representative traces showing sIPSCs in a $\mathrm{D}_{1}{ }^{+} \mathrm{MSN}$ (top) and a $\mathrm{D}_{2}{ }^{+} \mathrm{MSN}$ (bottom). Calibration: $1 \mathrm{~s}, 25 \mathrm{pA}$. Summary of the mean amplitude $(\boldsymbol{B})$, frequency of events $(\boldsymbol{C})$, tau values $(\boldsymbol{D})$, and rise time (E) for SIPSCs in $\mathrm{D}_{1}^{+}$and $\mathrm{D}_{2}{ }^{+} \mathrm{MSN}$. sIPSC values were measured using $\mathrm{KCl}$ internal (black bars; $n=6$ and 12) and with CsCl internal (white bars; $n=8$ and 10) from $\mathrm{D}_{1}{ }^{+}$and $\mathrm{D}_{2}{ }^{+} \mathrm{MSNs}$, respectively. $\mathbf{G}$, Representative traces demonstrate $\mathrm{mIPSCs}$ in a $\mathrm{D}_{1}{ }^{+} \mathrm{MSN}$ (top) and a $\mathrm{D}_{2}{ }^{+} \mathrm{MSN}$ (bottom). Calibration: $1 \mathrm{~s}, 25 \mathrm{pA}$. Summary of the mean amplitude $(\boldsymbol{H})$, frequency of events $(\boldsymbol{I})$, tau values $(\boldsymbol{J})$, and rise time $(\boldsymbol{K})$ for $\mathrm{mIPS}\left(\sin \mathrm{D}_{1}{ }^{+}\right.$and $\mathrm{D}_{2}{ }^{+} \mathrm{MSN}$. mIPS(S values were measured from the same cells represented in $\boldsymbol{B}-\boldsymbol{D}$ using $\mathrm{KCl}$ internal (black bars) and $\mathrm{CsCl}$ internal (white bars) by subsequent application of TTX ( $500 \mathrm{~nm})$, NBQX (5 $\mu \mathrm{M})$, and strychnine ( $500 \mathrm{~nm})$. Cumulative probability plots for the average mIPSC $(\boldsymbol{F})$, amplitude, and interevent interval $(\boldsymbol{L})$ from $\mathrm{D}_{1}{ }^{+} \mathrm{MSNs}$ (dashed black line; $n=9$ ) and $D_{2}{ }^{+}$MSNs (solid gray line; $n=10$ ) recorded with CSCl internal.

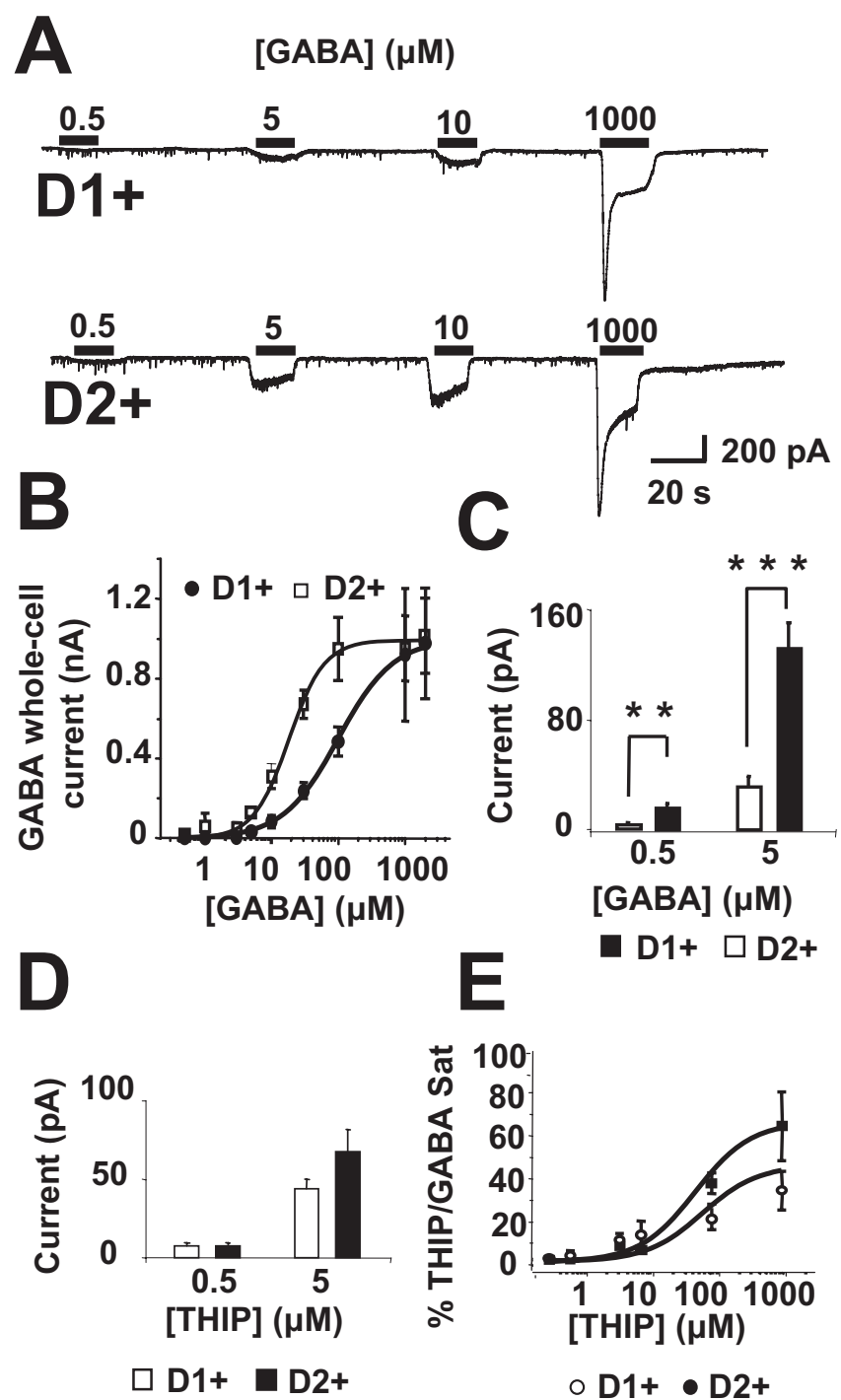

Figure 4. Greater sensitivity to exogenously applied GABA in $\mathrm{D}_{2}{ }^{+}$than in $\mathrm{D}_{1}{ }^{+} \mathrm{MSN}$. Representative traces $(\boldsymbol{A})$ and summary dose-response data $(\boldsymbol{B})$ of the whole-cell currents elicited by increasing doses of GABA applied in the presence of TTX $(0.5 \mu \mathrm{M}), \mathrm{NBQX}(5 \mu \mathrm{M})$, and strychnine $(0.5 \mu \mathrm{M})$ in $\mathrm{D}_{1}{ }^{+}$and $\mathrm{D}_{2}{ }^{+} \mathrm{MSN}$. The $\mathrm{EC}_{50}$ for GABA was $107.3 \pm 0.5$ and $18.2 \pm 1.9 \mu \mathrm{M}$ and the Hill coefficient was $1.04 \pm 0.05$ and $1.75 \pm 0.18$ for $\mathrm{D}_{1}{ }^{+}$and $\mathrm{D}_{2}{ }^{+} \mathrm{MSN}$, respectively. All recordings were performed with $\mathrm{KCl}$ internal solution, and data were derived from at least sixteen cells in each group. Data on whole-cell currents induced by $0.5 \mu \mathrm{m}$ and $5 \mu \mathrm{m} \mathrm{GABA} \mathrm{(} C$ ) for $\mathrm{D}_{1}{ }^{+} \mathrm{MSN}$ ( white bar) and $\mathrm{D}_{2}{ }^{+} \mathrm{MSN}$ (black bar) are illustrated for clarity. $D$, A summary of whole-cell currents elicited by $0.5 \mu \mathrm{m}$ and $5 \mu \mathrm{MTHIP}$ in $\mathrm{D}_{1}{ }^{+} \mathrm{MSNs}$ (white bars) and $\mathrm{D}_{2}{ }^{+} \mathrm{MSNs}$ (black bars). $E$, Dose-response data of whole-cell recordings of THIP elicited currents normalized to currents elicited by a saturating dose of GABA $\left(2 \mathrm{~mm} ; \mathrm{GABA}_{\mathrm{sat}}\right)$ in each cell. For both $D$ and $\boldsymbol{E}$, recordings were performed in the presence of TTX $(0.5 \mu \mathrm{M}), \mathrm{NBQX}(5 \mu \mathrm{M})$, and strychnine $(0.5$ $\mu \mathrm{M})$, and data were derived from at least six MSNs in each group.

portion of which are thought to contain the $\delta$ subunit. As illustrated in Figure $4 E$, the responses to high THIP concentrations normalized to the response to a saturating dose of GABA ( $2 \mathrm{mM})$ were larger in $\mathrm{D}_{2}{ }^{+}$than in $\mathrm{D}_{1}{ }^{+}$MSNs. These results mimic those seen with intermediate doses of GABA and were expected because of the loss of receptor selectivity at high concentrations. However, the two MSN subtypes were similar in their sensitivity to low doses of THIP (Fig. $4 D, E$ ), suggesting that $\mathrm{D}_{1}{ }^{+}$and $\mathrm{D}_{2}{ }^{+}$MSNs express a similar portion of $\delta$-subunit-containing $\mathrm{GABA}_{\mathrm{A}}$ receptors. However, interpretations from these experiments are limited because it has been shown that the functional selectivity of 


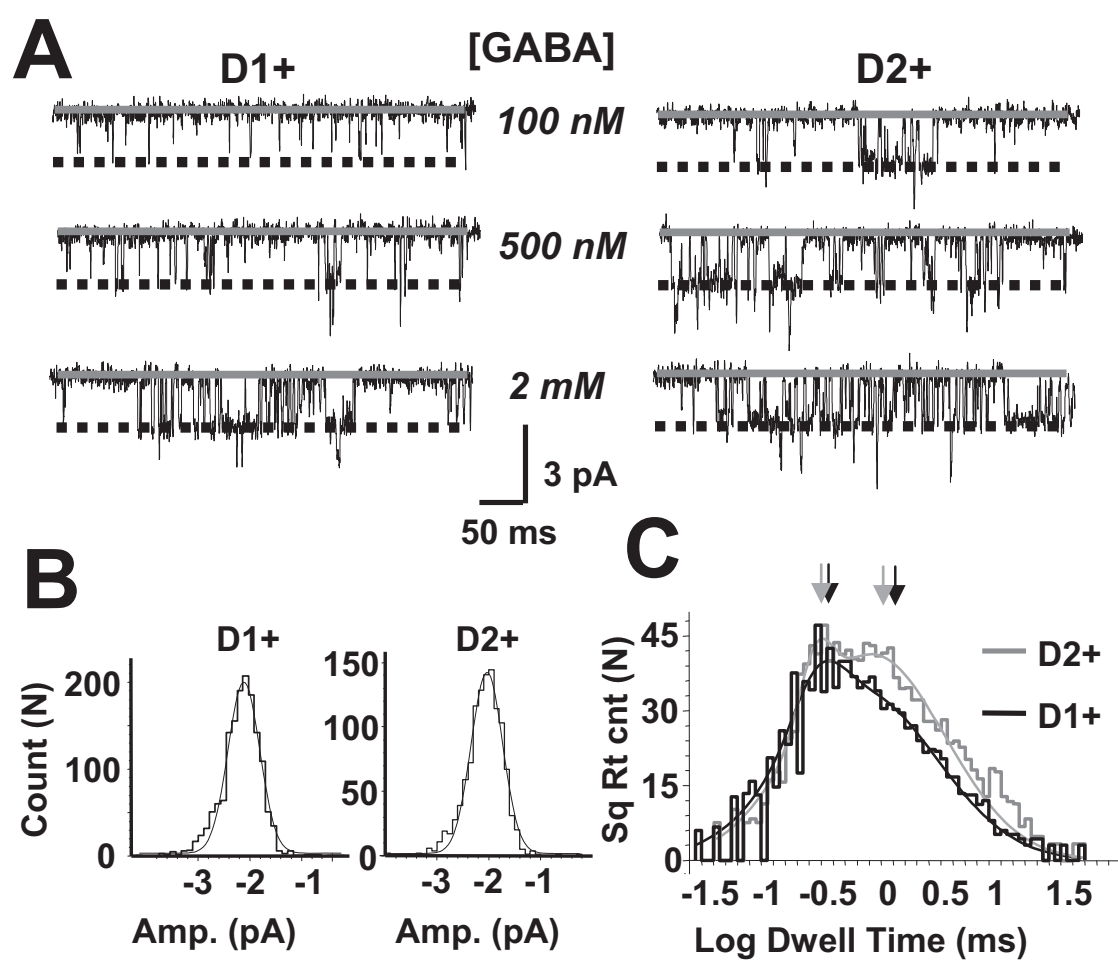

D

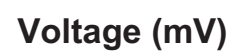

E
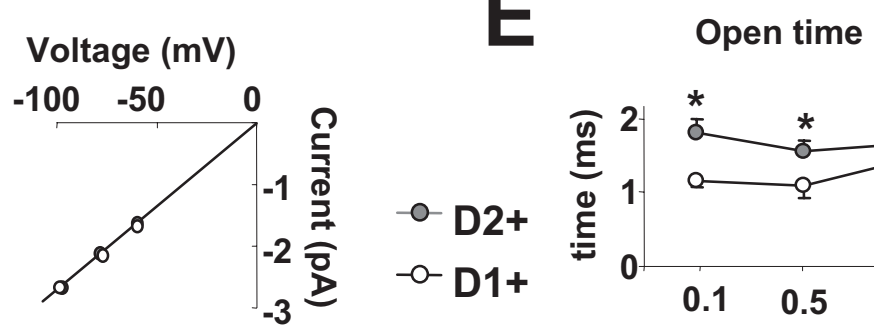

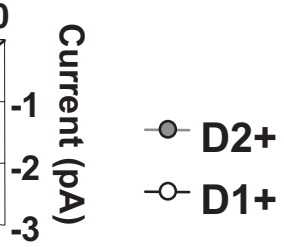

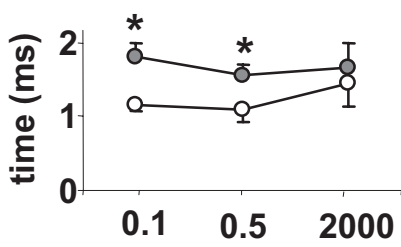

[GABA] $(\mu \mathrm{M})$
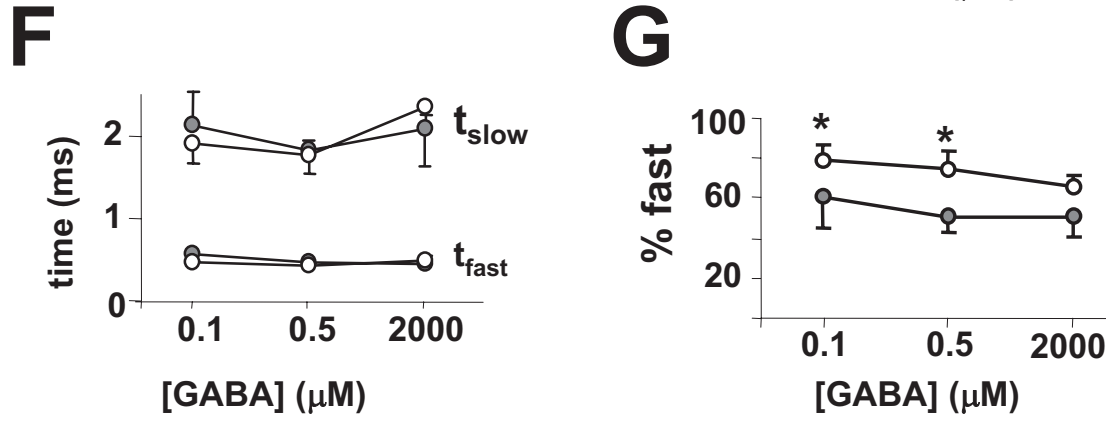

Figure 5. GABA channel currents in excised patches from $\mathrm{D}_{1}{ }^{+}$and $\mathrm{D}_{2}{ }^{+} \mathrm{MSN}$. $\boldsymbol{A}$, Representative examples of currents elicited by three concentrations of GABA (100 nm, $500 \mathrm{~nm}$, and $2 \mathrm{~mm}$ ) in patches excised from a $\mathrm{D}_{1}{ }^{+}$and a $\mathrm{D}_{2}{ }^{+}$MSN and held at $-80 \mathrm{mV}$. Dashed lines illustrate the main conductance level derived from channel current histograms shown in $\boldsymbol{B}$. Histograms were fit with a Gaussian, and the peak of the curve defined the main conductance level. The main opening levels for the channel currents elicited by $500 \mathrm{~nm}$ GABA in the patches represented in $\boldsymbol{A}$ were $2.18 \pm 0.09 \mathrm{pA}$ for the $\mathrm{D}_{1}{ }^{+}$ MSN and $2.19 \pm 0.08$ pA for the $D_{2}{ }^{+}$MSN. C, Overlapping open time distributions with a multiple Gaussian fit on a logarithmic scale for the patches illustrated in $\boldsymbol{A}$ elicited by $500 \mathrm{~nm} \mathrm{GABA.} \mathrm{Time} \mathrm{constants} \mathrm{of} \mathrm{the} \mathrm{distributions} \mathrm{indicated} \mathrm{by}$ arrows were $0.41 \mathrm{~ms}$ (fast) and $1.9 \mathrm{~ms}$ (slow) (81\% fast component) and $0.39 \mathrm{~ms}$ (fast) and $1.85 \mathrm{~ms}$ (slow) (59\% fast component) for the $\mathrm{D}_{1}{ }^{+}$and the $\mathrm{D}_{2}{ }^{+} \mathrm{MSN}$, respectively. $\boldsymbol{D}$, Current to voltage relationship for the main open state of GABA-elicited currents in patches excised from $\mathrm{D}_{1}{ }^{+}(n=9)$ and $\mathrm{D}_{2}{ }^{+}(n=8)$ MSNs. The slope conductance from the linear fits illustrated was $27.9 \pm 0.4$ and $27.5 \pm 0.4 \mathrm{pS}$ for the $\mathrm{D}_{1}{ }^{+}$and the $\mathrm{D}_{2}{ }^{+}$MSNs, respectively. $\boldsymbol{E}$, Summary of mean open times for the channel openings at the main conductance for three GABA concentrations. $\boldsymbol{F}$, Summary of the open time distributions for the two main open time constants as in $\boldsymbol{C}$ at each concentration tested. $\mathbf{G}$, Summary of the percentage contribution of the fast open time to the fit constant at the three concentrations of GABA.
THIP depends on the absence of the $\gamma 2$ subunit (Storustovu and Ebert, 2006). Therefore, responsiveness to low doses of THIP could not discriminate between $\alpha \beta \delta$ - and $\alpha \beta$-containing $\mathrm{GABA}_{\mathrm{A}}$ receptors (Ebert et al., 1997). Because $\alpha \beta$ receptors have been identified recently in vivo in rat hippocampal pyramidal neurons (Mortensen and Smart, 2006), we investigated the possibility that $\alpha \beta$ receptors mediate the tonic current in $\mathrm{D}_{2}{ }^{+}$MSNs by recording single channel currents in excised patches, because $\mathrm{GABA}_{\mathrm{A}}$ receptors, which solely comprise $\alpha$ and $\beta$ subunits, have been shown to have lower conductance levels than those receptors that contain a $\gamma$ or $\delta$ subunit (Verdoorn et al., 1990; Fisher and Macdonald, 1997).

Single GABA channel currents in MSNs GABA was applied at increasing concentrations, and activated channel currents in patches were excised from both types of MSNs (Fig. 5). Because the patches usually contained multiple channels, we restricted our analysis to recording segments that demonstrated a unitary conductance and skipped segments with multiple openings. The presence of multiple channels prevented us from assessing the closed intervals and burst durations, but we could measure both the current amplitude and open time for those channels present in the patch. In both types of MSNs, channel current amplitudes with low main conductance states $(<20 \mathrm{pS})$ made up $<10 \%$ of the total channel openings, suggesting that, if $\alpha \beta$ channels are present, they make up only a small portion of the total $\mathrm{GABA}_{\mathrm{A}}$ receptors. As seen in Figure 5B, amplitude histograms of openings at the main conductance state elicited by $500 \mathrm{~nm}$ GABA in patches from a $\mathrm{D}_{1}{ }^{+}$and $\mathrm{D}_{2}{ }^{+}$MSN held at $-80 \mathrm{mV}$ were fitted by single Gaussians with similar peak amplitudes. The summary values for the slope conductance of the main state determined from three separate holding voltages in each patch from nine $\mathrm{D}_{1}{ }^{+}$and eight $\mathrm{D}_{2}{ }^{+}$MSNs are reported in Figure $5 D$, showing that this channel property did not differ between the two MSN subtypes. As shown in Figure $5 C$, the open time of channel currents elicited by $500 \mathrm{~nm}$ GABA in patches from the $\mathrm{D}_{2}{ }^{+}$and $\mathrm{D}_{1}{ }^{+}$MSN revealed two kinetic components. The fast open time constant and slow open time constant derived from the fitting of the open time distributions did not differ between MSNs (Fig. 5F). However, at low concentrations of GABA (100 and $500 \mathrm{nM}$ ), the percentage contribution of the longer component to the mean open time was remarkably larger in patches 
from $\mathrm{D}_{2}{ }^{+}$than $\mathrm{D}_{1}{ }^{+}$MSNs. Although the percentage contribution of the fast component remained stable across all concentrations of GABA in the $\mathrm{D}_{2}{ }^{+} \mathrm{MSNs}$, the percentage contribution of the fast component to the fit was reduced at higher GABA concentrations in the $\mathrm{D}_{1}{ }^{+}$MSNs (Fig. 5G), indicating that there is a concentration dependence for the mean channel open time in patches from $\mathrm{D}_{1}{ }^{+}$but not $\mathrm{D}_{2}{ }^{+}$MSNs. Similar to the responses seen in the whole-cell currents (Fig. $4 B$ ), mean channel open times did not significantly differ between the two cell types in response to saturating doses of GABA $(2 \mathrm{~mm})$ but were significantly different at lower GABA concentrations (Fig. 5E).

\section{Contribution of the $\alpha 1$ subunit in tonic and phasic inhibition in MSNs}

A novel GABA $\mathrm{A}_{\mathrm{A}}$ receptor containing $\alpha 1$ and $\delta$ subunits has been discovered recently in hippocampal interneurons (Glykys et al., 2007 ). Because THIP sensitivity of $\alpha 1 \beta \delta$ receptors has yet to be reported, we could not rely on the data from the THIP doseresponse curves to assess the presence of such a receptor. Therefore, we investigated the role of the $\alpha 1$ subunit in tonic and phasic GABA currents in MSNs by recording from slices prepared from $\alpha 1^{-/-}$mice. Although we were unable to determine whether the MSNs were $\mathrm{D}_{1}{ }^{+}$or $\mathrm{D}_{2}{ }^{+}$, there was a large variability in the magnitude of tonic currents seen within MSNs with this genotype (Fig. 6A,C), as would be expected because data were likely derived from both MSN subtypes. For comparison, Figure $6 C$ also reports tonic current in an equally proportioned sample of $\mathrm{D}_{1}{ }^{+}$ and $\mathrm{D}_{2}{ }^{+} \mathrm{MSN}$ recorded from the BAC EGFP mice. These data suggest that the deletion of $\alpha 1$ subunit fails to affect tonic GABA currents in striatal MSNs, a notion that was further supported by our finding that $100 \mathrm{~nm}$ zolpidem (a benzodiazepine agonist selective for $\alpha 1$ subunit at low doses) failed to show consistent effects on tonic currents in either cell type. Conversely, as has been shown in hippocampal neurons (Goldstein et al., 2002), the tau values for the synaptic events in MSNs from $\alpha 1^{-1-}$ mice were significantly longer than that seen in age-matched BAC EGFP mice (Fig. $6 B, D$ ). Furthermore, $100 \mathrm{~nm}$ zolpidem prolonged sIPSCs in both $\mathrm{D}_{1}{ }^{+}(119 \pm 8 \%$ of control, $n=5, p<0.05)$ and $\mathrm{D}_{2}{ }^{+}$ MSNs ( $126 \pm 8 \%$ of control, $n=5, p<0.05$ ), demonstrating that $\alpha 1$-subunit-containing $\mathrm{GABA}_{\mathrm{A}}$ receptors do contribute to GABA-mediated postsynaptic currents in striatal MSNs.

\section{Tonic GABA conductances in MSNs are mediated by} receptors containing the $\alpha 5$ subunit

Although our data support previously reported findings that MSNs express the $\delta$ subunit (Pirker et al., 2000; Schwarzer et al., 2001 ), it argues against the hypothesis that differential $\delta$ subunit expression between the two MSN subtypes underlies the difference seen in tonic inhibition. Therefore, we sought to investigate whether tonic GABA currents in MSNs is mediated by $\alpha 5$ subunit-containing $\mathrm{GABA}_{\mathrm{A}}$ receptors as has been shown in hippocampal pyramidal neurons (Caraiscos et al., 2004; Scimemi et al., 2005) and somatosensory cortex layer $\mathrm{V}$ pyramidal cells (Yamada et al., 2007). Indeed, L655,708, an inverse agonist with high selectivity for $\mathrm{GABA}_{\mathrm{A}}$ receptors containing the $\alpha 5$ subunit (Quirk et al., 1996) at concentrations ranging from $50 \mathrm{~nm}$ to 10 $\mu \mathrm{M}$, reduced tonic GABA currents in the $\mathrm{D}_{2}{ }^{+} \mathrm{MSNs}$ (Fig. 7). Because $\mathrm{D}_{1}{ }^{+}$MSNs show little tonic GABA currents under normal recording conditions, we bath applied $1 \mu \mathrm{M}$ GABA, which enhanced both tonic and phasic charge transfer, and measured the effects of subsequent application of L655,708 in both MSN populations (Fig. 7C). Under these conditions, the inverse agonist still blocked a significantly larger percentage of the GABA

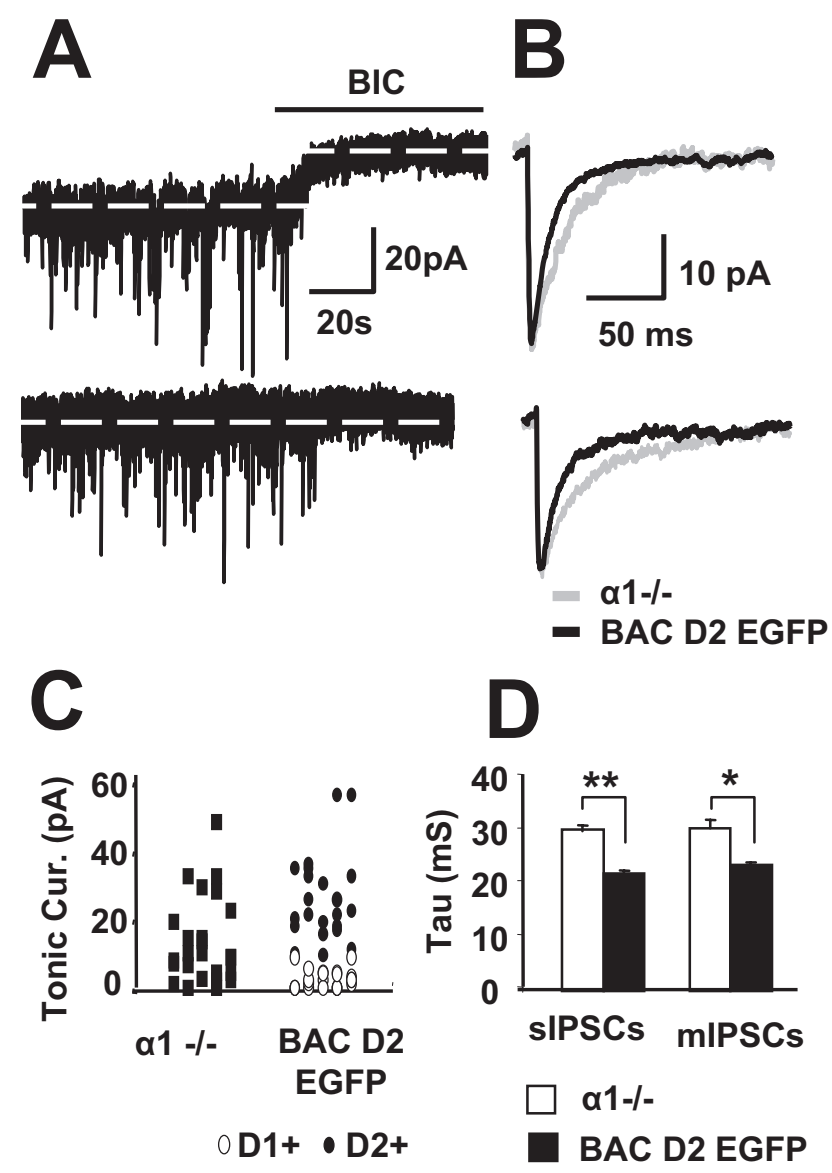

Figure 6. The role of the $\alpha 1$ subunit in MSN tonic and phasic inhibition. $\boldsymbol{A}$, Representative traces demonstrate the occurrence of SIPSCs and the response to BIC in two examples of MSNs in striatal slices derived from a postnatal day $19 \alpha 1^{-/-}$mouse. $\boldsymbol{B}$, Overlaying representative traces of sIPSCs (top) and mIPSCs (bottom) from MSNs in $\alpha 1^{-/-}$(gray) and BAC $D_{2}$ EGFP (black) mice. $C$, Comparison of the distributions of BIC-sensitive tonic currents in 21 MSNs from $\alpha 1^{-1-}$ mice and a sample of $15 D_{1}{ }^{+}$and $15 D_{2}{ }^{+}$MSNs from BAC D EGFP mice illustrates a similar scatter. $D$, Summary of mean tau values for sIPSCs and mIPSCs in MSNs from $12 \alpha 1^{-1-}$ (white bars) and a pool of six $D_{1}{ }^{+}$and six $D_{2}{ }^{+}$MSNs from age-matched BAC $D_{2}$ EGFP mice (black bars).

tonic current in $\mathrm{D}_{2}{ }^{+}$than in $\mathrm{D}_{1}{ }^{+}$MSNs (Fig. 7D). Additionally, we measured the effects of L655,708 on IPSC amplitude and decay time in MSNs because it has been shown to reduce both of these measures of phasic inhibition in cortical pyramidal cells (Ing and Poulter, 2007). Although low concentrations of L655,708 (50 nM) did not significantly affect sIPSC charge in either cell type, a higher concentration of the inverse agonist (10 $\mu \mathrm{M})$ significantly decreased both the sIPSC amplitude and decay time in $\mathrm{D}_{2}{ }^{+}$but not $\mathrm{D}_{1}{ }^{+}$MSNs.

To complement the electrophysiological results, expression of $\alpha 5$ was determined with immunofluorescent labeling using antibodies against the $\alpha 5$ subunit as described by Fritschy and Mohler (1995). The results revealed that both $\mathrm{D}_{1}{ }^{+}$and $\mathrm{D}_{2}{ }^{+}$ MSNs were immunopositive for the $\alpha 5$ subunit (supplemental Fig. S2, available at www.jneurosci.org as supplemental material). However, quantification of the relative cluster distribution and fluorescence intensity showed that $\mathrm{D}_{2}{ }^{+}$MSNs have significantly greater level of immunofluorescence than $\mathrm{D}_{1}{ }^{+} \mathrm{MSN}$. The number of clusters normalized to the cell area was $17.8 \pm 2.3$ for $42 \mathrm{D}_{1}{ }^{+}$MSNs and $25.4 \pm 1.8$ for $50 \mathrm{D}_{2}{ }^{+}$MSNs, $(p<0.01)$. However, no difference was seen in average fluorescence intensity. Because we saw no difference in synaptic inhibitory currents 

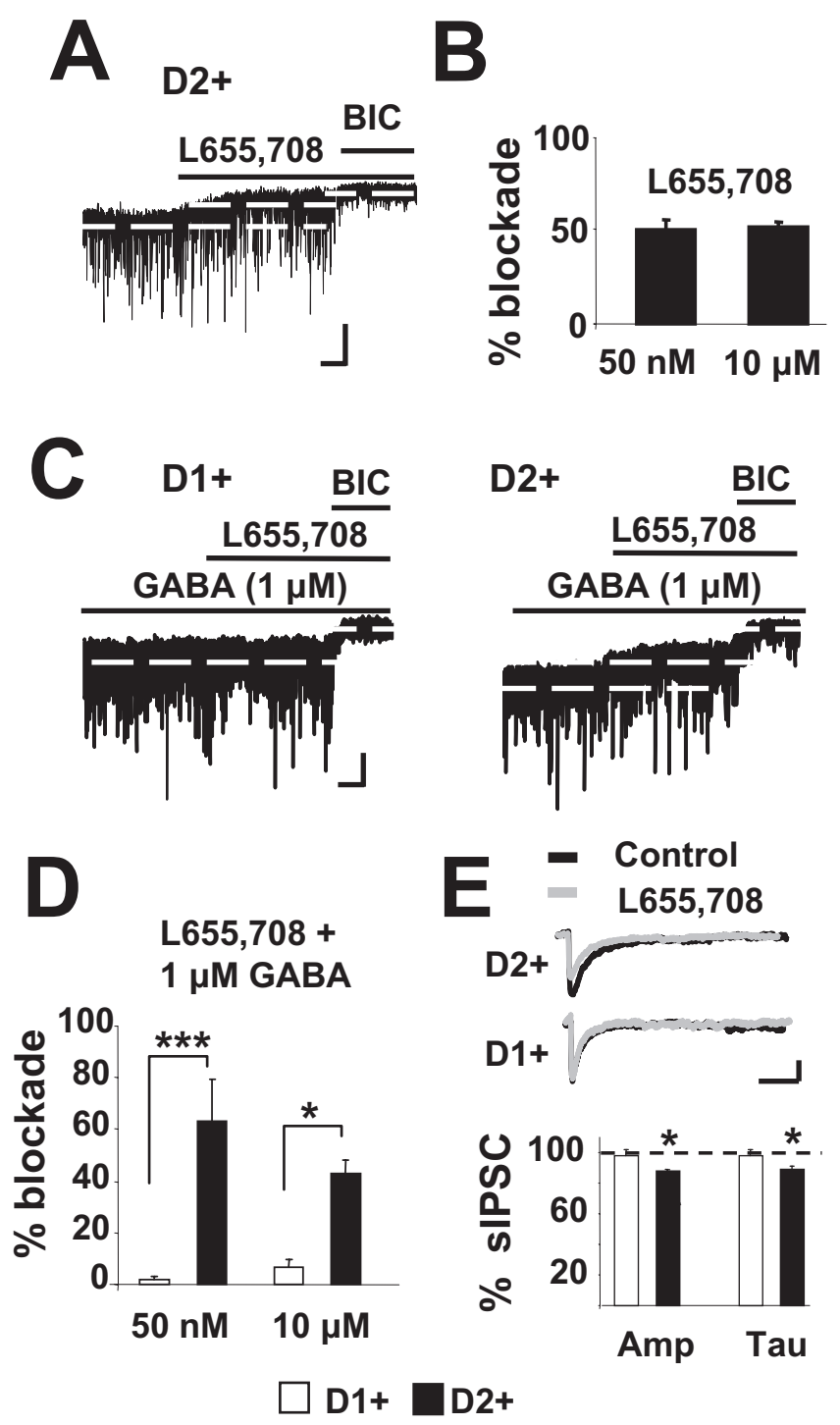

Figure 7. L655,703 antagonizes $\mathrm{GABA}_{\mathrm{A}}$ receptor-mediated tonic currents in $\mathrm{D}_{2}{ }^{+} \mathrm{MSN}$ s. $\boldsymbol{A}$, Representative trace showing the effects of $\mathrm{L} 655,703(10 \mu \mathrm{M})$ on sIPSCs and on BIC-sensitive tonic current in a $\mathrm{D}_{2}{ }^{+} \mathrm{MSN}$. Calibration: $20 \mathrm{~ms}, 30 \mathrm{pA}$. B, Summary of tonic current blocked by L655,703 (50 nM, $n=4 ; 10 \mu \mathrm{m}, n=8)$ in $\mathrm{D}_{2}{ }^{+}$MSNs. C, Representative traces showing the effects of $\mathrm{L} 655,703(10 \mu \mathrm{M})$ on sIPSCs and BIC-sensitive tonic currents elicited by bath application of $1 \mu \mathrm{MGABA}$ in a $\mathrm{D}_{1}{ }^{+} \mathrm{MSN}$ and a $\mathrm{D}_{2}{ }^{+} \mathrm{MSN}$. Calibration: $20 \mathrm{~ms}, 30 \mathrm{pA}$. D, Summary of the percentage blockade by $L 655,708$ of the BIC-sensitive tonic current elicited by bath application of $1 \mu \mathrm{MGABA}$ in $\mathrm{D}_{1}{ }^{+} \mathrm{MSNs}(100 \mathrm{~nm}, n=3 ; 10 \mu \mathrm{m}, n=5)$ and in $\mathrm{D}_{2}{ }^{+} \mathrm{MSNs}(50 \mathrm{~nm}, n=2 ; 10$ $\mu \mathrm{M}, n=4) . E$, Representative traces showing overlapping sIPSCs recorded in a $\mathrm{D}_{1}{ }^{+} \mathrm{MSN}$ (top) and a $\mathrm{D}_{2}{ }^{+} \mathrm{MSN}$ (middle) in the presence (gray trace) and the absence (black trace) of $10 \mu \mathrm{M}$ L655,703, as well as the summary of the changes in sIPSC amplitude (Amp) and decay time (Tau) produced by $10 \mu \mathrm{m} L 655,703$ in six $\mathrm{D}_{1}{ }^{+}$and seven $\mathrm{D}_{2}{ }^{+}$MSNs (bottom) represented as percentage of baseline values. Calibration: $20 \mathrm{~ms}, 30 \mathrm{pA}$.

and the $\alpha 2$ subunits are the predominate subunit expressed on both $\mathrm{D}_{1}{ }^{+}$and $\mathrm{D}_{2}{ }^{+}$MSNs in the striatum (Pirker et al., 2000), we repeated the immunostaining procedure with an antibody against the $\alpha 2$ subunit. As expected, results showed no difference in $\alpha 2$ clusters normalized to cell area between $\mathrm{D}_{1}{ }^{+}$and $\mathrm{D}_{2}{ }^{+}$ MSNs $\left(28.6 \pm 4.7\right.$ for $30 \mathrm{D}_{1}{ }^{+}$MSNs and $24.3 \pm 2.6$ for $32 \mathrm{D}_{2}{ }^{+}$ MSNs). Together, the data from the pharmacological and immunofluorescence studies suggest that the two populations differ in $\alpha 5$-subunit- but not $\alpha 2$-subunit-containing $\mathrm{GABA}_{\mathrm{A}}$ receptor expression.
Physiological role of tonic current in MSNs

The observation of a GABA tonic current in striatopallidal but not the striatonigral MSNs raises important questions as to the physiological role for this tonic current, especially given the recent findings that striatopallidal MSNs fire at higher frequency both in vivo (Mallet et al., 2006) and in response to a depolarizing current injection in whole-cell recordings in slice (Kreitzer and Malenka, 2007). The reversal potential for $\mathrm{Cl}^{-}\left(E_{\mathrm{Cl}}\right)$ in MSNs has been shown to be approximately $-76 \mathrm{mV}$ (Koos et al., 2004), which is more depolarized than the average RMP reported in the slice (Shen et al., 2005; Kreitzer and Malenka, 2007), suggesting that GABA may have a depolarizing effect in the MSNs. Thus, one could expect $\mathrm{D}_{1}{ }^{+}$and $\mathrm{D}_{2}{ }^{+}$MSNs to differ in both input resistance and RMP as a result of the tonic GABA channel conductance in $\mathrm{D}_{2}{ }^{+}$cells. However, in agreement with the study of Kreitzer and Malenka (2007), we did not see differences in either of these parameters. In a subset of seven $\mathrm{D}_{1}{ }^{+}$and eight $\mathrm{D}_{2}{ }^{+}$ MSNs, current-clamp recordings at room temperature with K-gluconate internal showed that the input resistance was $224 \pm$ 19 and $198 \pm 21 \mathrm{M} \Omega$, respectively. Furthermore, we assessed the RMP in our preparation by estimating the $E_{\mathrm{K}}$ with a series of command voltage ramps given in cell-attached configuration with isotonic potassium in the pipette, a condition that leaves intracellular $\mathrm{Cl}^{-}$levels unperturbed as in the study by Verheugen et al. (1999) (see Materials and Methods) (supplemental Fig. S3A, available at www.jneurosci.org as supplemental material). Although no significant differences in RMP were found between the $\mathrm{D}_{1}{ }^{+}(-80.9 \pm 1.9 \mathrm{mV}, n=22)$ and $\mathrm{D}_{2}{ }^{+}(-80.0 \pm 1.9 \mathrm{mV}, n=$ 15) MSNs, application of $5 \mu \mathrm{M}$ GABA induced greater depolarization of $\mathrm{D}_{2}{ }^{+}$than $\mathrm{D}_{1}{ }^{+}$MSNs (supplemental Fig. S3, available at www.jneurosci.org as supplemental material). Furthermore, in $\mathrm{D}_{2}{ }^{+}$MSNs, but not in $\mathrm{D}_{1}{ }^{+}$MSNs, application of both L655,708 $(50 \mathrm{nM})$ and GBZ $(10 \mu \mathrm{M})$ significantly hyperpolarized the RMP (supplemental Fig. S3B, available at www.jneurosci.org as supplemental material).

To further assess the effects of endogenous GABA tonic currents on MSN excitability, we investigated the action of gabazine $(10 \mu \mathrm{M})$ on action potential firing patterns by performing current-clamp recordings in six $\mathrm{D}_{1}{ }^{+}$and six $\mathrm{D}_{2}{ }^{+}$MSNs with $\mathrm{K}$-gluconate internal. In agreement with a recent report (Kreitzer and Malenka, 2007), $\mathrm{D}_{2}{ }^{+}$MSNs demonstrated a higher firing frequency than $\mathrm{D}_{1}{ }^{+}$MSNs in response to depolarizing current injections (Fig. $8 \mathrm{~B}$ ) despite a similar input resistance (see above) and same starting membrane potential $(-65 \mathrm{mV}$; see Materials and Methods). In this experimental conditions, the $\mathrm{GABA}_{\mathrm{A}}$ receptor antagonist slightly hyperpolarized both $\mathrm{D}_{1}{ }^{+}(0.16 \pm 0.09$ $\mathrm{mV})$ and $\mathrm{D}_{2}{ }^{+}(0.48 \pm 0.16 \mathrm{mV}) \mathrm{MSNs}$, and, interestingly, it decreased the firing rate in $\mathrm{D}_{2}{ }^{+}$but not $\mathrm{D}_{1}{ }^{+}$MSNs (Fig. 8 A,B). This decrease in firing rate is the converse of effects seen in the cerebellum and thalamus in which blockade of tonic GABA currents increases action potential firing rate in response to depolarizing current injections (Brickley et al., 1996; Cope et al., 2005).

Although we found these results to be intriguing, we reasoned that depolarizing current injections at the soma in whole-cell configuration are unlikely to mimic the conditions that generate action potentials under normal physiological conditions. Therefore, we sought to verify whether tonic GABA currents would also reduce the efficacy of excitatory afferents in generating action potentials in MSNs in conditions in which internal $\mathrm{Cl}^{-}$concentrations were not disrupted. To address this issue, a bipolar stimulating electrode was placed within the white matter at the corticostriatal border and was delivered square-wave electric pulses to the glutamatergic striatal afferents as in the study by Ade and 

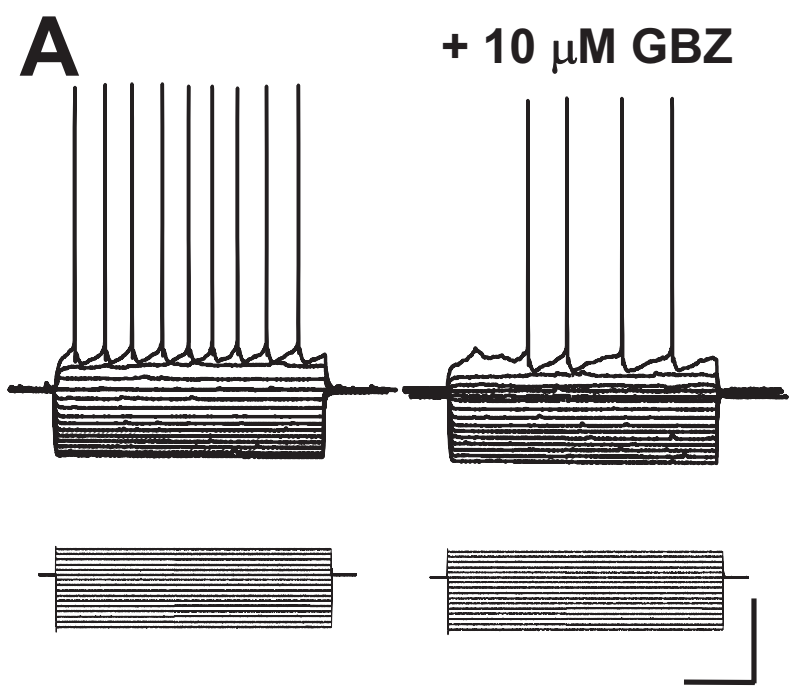

$200 \mathrm{~ms}$

$B$
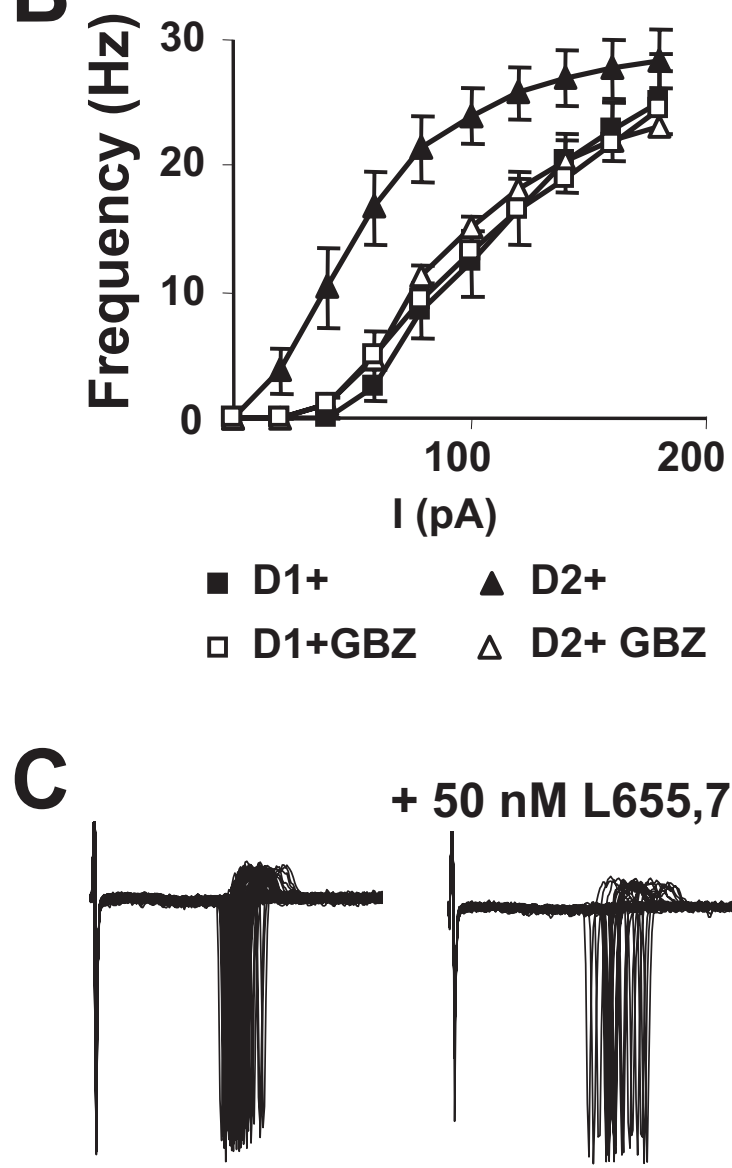

$+50 \mathrm{nM} \mathrm{L655,703}$

Figure 8. Blocking $G A B A_{A}$ receptor currents reduces action potential firing frequency in $D_{2}{ }^{+}$ MSNs. $A$, Representative example of a current-clamp recording from a $\mathrm{D}_{2}{ }^{+} \mathrm{MSN}$ illustrating the responses to a series of hyperpolarizing and depolarizing current injections ( $20 \mathrm{pA}$ steps) recorded with K-gluconate internal in the absence and the presence of $10 \mu \mathrm{m}$ gabazine. Calibration: $15 \mathrm{mV}, 80 \mathrm{pA}$. $\boldsymbol{B}$, Summary of action potential firing frequency in response to increasing depolarizing current injections recorded with K-gluconate internal solution in $D_{1}{ }^{+}(\square)$ and $\mathrm{D}_{2}{ }^{+}(\mathbf{\Delta})$ MSNs the absence or the presence $\left[\mathrm{D}_{1}{ }^{+}(\square)\right.$ and $\left.\mathrm{D}_{2}{ }^{+}(\triangle)\right]$ of $10 \mu \mathrm{m}$ gabazine. Data derive from six $\mathrm{D}_{1}{ }^{+}$and seven $\mathrm{D}_{2}{ }^{+}$MSNs. $\boldsymbol{C}$, Representative example of a $\mathrm{D}_{2}{ }^{+}$MSN demonstrates action potential firing evoked by stimulation of glutamatergic afferents and assessed using extracellular recording in cell-attached configuration in the absence (left) or the presence (right) of $50 \mathrm{~nm}$ L655,703. Calibration: $3 \mathrm{~ms}, 40 \mathrm{pA}$.
Lovinger (2007). These stimuli-evoked action potentials were recorded in loose cell-attached configuration using aCSF-filled pipettes. As seen in Figure 8C, the success rate for evoked spike generation derived from stimulating glutamatergic afferent fibers was significantly decreased by perfusion of $50 \mathrm{~nm}$ L655,708 in five $\mathrm{D}_{2}{ }^{+}$MSNs $(60 \pm 20 \%)$ but not three $\mathrm{D}_{1}{ }^{+}$MSNs (117 $\left.\pm 4 \%\right)$.

\section{Discussion}

In this study, we demonstrate that $\mathrm{D}_{2}{ }^{+}$MSNs display larger $\mathrm{GABA}_{\mathrm{A}}$ receptor-mediated tonic currents than the $\mathrm{D}_{1}{ }^{+}$MSNs. Whole-cell and single-channel current recordings suggest that $\mathrm{D}_{2}{ }^{+}$MSNs are more sensitive to low doses of GABA than $\mathrm{D}_{1}{ }^{+}$ MSNs. Furthermore, the findings that the two MSN populations were similar in their synaptic input and in their response to GAT-1 inhibition provide strong evidence that the differences in tonic GABA currents seen in the slice preparation are likely mediated by a difference in receptor expression or function, and the strong TTX sensitivity of MSN tonic GABA currents suggests that action potential-mediated synaptic release is the major source for ambient GABA in the striatum and that tonic GABA conductances in the MSNs are very sensitive to local changes in ambient GABA concentration in the striatum.

The higher detection rate of sIPSCs and mIPSCs in both cell types and the larger tonic currents detected in $\mathrm{D}_{2}{ }^{+}$MSNs using $\mathrm{CsCl}$ internal rather than $\mathrm{KCl}$ internal is reflective of previous findings that cesium-based internal solutions showed enhanced mEPSC detection over potassium-based internal solutions (Day et al., 2006) and lends additional credence to the proposition that cesium-based internal solutions allow for current detection over larger expanses of the plasma membrane.

Interestingly, mIPSC amplitude in $\mathrm{D}_{1}{ }^{+}$but not in $\mathrm{D}_{2}{ }^{+} \mathrm{MSNs}$ was significantly larger with $\mathrm{CsCl}$ internal, suggesting that quantal size is potentially larger at distally located inhibitory synapses in $\mathrm{D}_{1}{ }^{+}$MSNs. However, it may also simply indicate that $\mathrm{D}_{1}{ }^{+}$ MSNs have more $\mathrm{K}^{+}$channel-mediated leak conductance, in agreement with previous reports that $\mathrm{D}_{1}$ receptor but not $\mathrm{D}_{2}$ receptor stimulation enhances subthreshold $\mathrm{K}^{+}$channel conductances (Pacheco-Cano et al., 1996) and may explain why input resistance does not significantly differ between the two cell types despite the rather selective occurrence of tonic GABA currents in $\mathrm{D}_{2}{ }^{+}$MSNs.

In this study, we used a combination of approaches in an attempt to define the $\mathrm{GABA}_{\mathrm{A}}$ receptor subtype responsible for MSN tonic GABA currents. The single-channel recordings suggest that main conductance levels for GABA channels in $\mathrm{D}_{1}{ }^{+}$and $\mathrm{D}_{2}{ }^{+}$MSNs are similar and that most channels contained either $\gamma$ or $\delta$ subunits. Indeed, the sensitivity of MSNs to the $\delta$-subunitpreferring agonist THIP agrees with previous reports of striatal $\delta$ subunit expression (Pirker et al., 2000). Thus, the combined sensitivity to THIP and single-channel data suggest that MSNs express $\delta$-subunit-containing $\mathrm{GABA}_{\mathrm{A}}$ receptors. However, the two subtypes did not differ in THIP sensitivity; therefore, it is unlikely that differential expression of $\delta$-subunit-containing receptors mediates the larger tonic currents and higher sensitivity to GABA in the $\mathrm{D}_{2}{ }^{+}$cells. Although high THIP sensitivity could be also be explained by the presence of $\alpha \beta$ receptors (Storustovu and Ebert, 2006), the rather limited occurrence of lower conductance channel openings in the single-channel recordings argue against this possibility.

Although we were unable to identify whether the MSNs in the $\alpha 1^{-1-}$ were striatopallidal or striatonigral, the distribution of tonic currents was similar to that seen in pooled MSNs of both subtypes from BAC $\mathrm{D}_{2}$ EGFP mice. Although it is important to 
note that deletion of certain $\alpha$ subunits may be compensated for by an upregulation of other $\alpha$ subunits (for review, see Vicini and Ortinski, 2004), changes in $\mathrm{K}^{+}$conductances (Brickley et al., 2001), or reduced GABA uptake (Ortinski et al., 2006), our data from the $\alpha 1^{-1-}$ in conjunction with the lack of potentiation of tonic current by zolpidem in the $\mathrm{D}_{2}{ }^{+} \mathrm{MSNs}$ (in the $\mathrm{BAC} \mathrm{D}_{2}$ EGFP mice) suggests that the $\alpha 1$-subunit-containing $\mathrm{GABA}_{\mathrm{A}}$ receptors do not mediate tonic GABA currents in MSNs. However, the findings of the longer IPSC tau in the $\alpha 1^{-1-}$ and the prolongation of the sIPSC tau by zolpidem in $\mathrm{BAC}_{2}$ EGFP mice suggest that some synaptic currents in MSNs are mediated by $\alpha 1$ subunit-containing $\mathrm{GABA}_{\mathrm{A}}$ receptors.

Because $\alpha 5$-subunit-containing $\mathrm{GABA}_{\mathrm{A}}$ receptors mediate tonic inhibition in other brain regions (Caraiscos et al., 2004; Scimemi et al., 2005; Yamada et al., 2007) and this subunit is expressed in the striatum (Pirker et al., 2000; Schwarzer et al., 2001), we studied the action of a selective inverse agonist of these receptors. Although micromolar concentrations of L655,708 have been used in the majority of brain slice physiology studies (Caraiscos et al., 2004; Scimemi et al., 2005; Yamada et al., 2007), pharmacological analysis of recombinant $\mathrm{GABA}_{\mathrm{A}}$ receptors (Quirk et al., 1996) would suggest that nanomolar concentrations should be as efficacious. Indeed, we found that $50 \mathrm{nM} \mathrm{L655,708}$ was as efficacious in antagonizing tonic currents in $\mathrm{D}_{2}{ }^{+}$MSNs as the higher concentrations $(10 \mu \mathrm{M})$. However, tonic currents in $\mathrm{D}_{1}{ }^{+}$MSNs induced by adding exogenous GABA as in the study by Scimemi et al. (2005) were not significantly reduced by either $50 \mathrm{nM}$ or $10 \mu \mathrm{M}$ L655,708, suggesting that $\mathrm{D}_{1}{ }^{+} \mathrm{MSN}$ s only have a small or negligible expression of $\alpha 5$-subunit-containing receptors. However, our immunofluorescence results argue that $\alpha 5$ subunit-containing receptors are found in both MSN subtypes, although slightly more abundant in $\mathrm{D}_{2}{ }^{+}$ones. Clearly, additional studies are necessary to determine whether differential surface expression or posttranslational regulation underlies the discrepancy.

L655,708 reduced sIPSC charge in the $\mathrm{D}_{2}{ }^{+}$but not the $\mathrm{D}_{1}{ }^{+}$ MSNs, although the effect was limited to the higher concentrations of the drug $(10 \mu \mathrm{M})$. If this is indeed a specific effect of blocking $\alpha 5$-subunit-containing receptors, it may relate to pharmacological differences in efficacy when GABA is released at high concentrations as it is at the synapse compared with the low ambient concentrations that activate tonic receptors. Alternatively, the effects at $10 \mu \mathrm{M}$ L655,708 may be mediated by receptors that do not contain the $\alpha 5$ subunit. If synaptic receptors are indeed different between $\mathrm{D}_{1}{ }^{+}$and $\mathrm{D}_{2}{ }^{+}$MSN, why did we not observe differences in properties of sIPSCs? It is possible that a compensatory expression of other subunit isoforms in the $\mathrm{D}_{1}{ }^{+}$ MSNs may allow for similar synaptic decay kinetics.

Among the $\mathrm{GABA}_{\mathrm{A}}$ receptor subunits found in striatal MSNs, of particular interest are $\beta 1$ and $\beta 3$ subunits (Flores-Hernandez et al., 2000; Pirker et al., 2000; Schwarzer et al., 2001) because they are potential targets for protein kinase A (PKA) phosphorylation. PKA is differentially regulated by the dopamine $D_{1}$ and dopamine $D_{2}$ receptor classes, and the effects of the phosphorylation are dependent on the $\beta$ subunit involved. Therefore, it will be interesting to determine how $\beta$ subunits regulate GABA sensitivity in MSNs in future studies once selective blockers of the $\beta$ subunits become available. In parallel, it will be essential to determine the effects of dopamine depletion on expression and function of striatal $\mathrm{GABA}_{\mathrm{A}}$ receptors because previous reports have suggested that dopamine depletion induces postsynaptic changes in GABA sensitivity that exacerbate the imbalance of striatal output (Mallet et al., 2006).
Our study confirmed previous findings (Kreitzer and Malenka, 2007) that, in the slice, $\mathrm{D}_{2}{ }^{+} \mathrm{MSN}$ fire action potentials in response to depolarizing current injection at higher frequency than $\mathrm{D}_{1}{ }^{+}$MSNs. However, in contrast to what is seen in the cerebellum and thalamus (Brickley et al., 1996; Cope et al., 2005), gabazine application actually shifted the spike rate versus injected current relationship for $\mathrm{D}_{2}{ }^{+} \mathrm{MSN}$ to the right to values seen in $\mathrm{D}_{1}{ }^{+}$MSNs (Fig. $8 \mathrm{~B}$ ), a finding that also seems to contradict the findings of similar RMP and input resistance for the two MSN subtypes (our data and Kreitzer and Malenka, 2007). RMP assessed by measuring $E_{\mathrm{K}}$ in a cell- attached patch showed values more negative than the IPSC reversal potential reported by others (Koos et al., 2004). Indeed, our recordings verified that GABA mildly depolarizes MSNs in slice, as has been shown both in vivo (Mercuri et al., 1991) and in organotypic corticostriatal culture preparations (Blackwell et al., 2003). Thus, the gabazine-induced reduction in excitability may be explained by the relative gap between MSN RMP and the GABA current reversal potential or potentially by the associated changes in $\mathrm{K}^{+}$channel conductances and calls for further modeling of the complex interactions of GABA tonic conductances with the other ionic currents found in MSNs (Wolf et al., 2005). However, the possibility exists that gabazine may affect MSN excitability indirectly by modulating the activity of neighboring cholinergic or GABAergic interneurons or by nonspecific actions at receptors in the MSNs.

The presence of tonic GABA currents has important consequences for synaptic excitation of MSNs. Synaptically evoked MSN firing was significantly reduced in $\mathrm{D}_{2}{ }^{+}$MSNs when tonic conductance was blocked by L655,708 (Fig. 8C,D). Future studies will have to verify that this effect is mediated by reduction of tonic GABAergic conductances in MSNs. It remains to be assessed how this regulation of synaptic efficacy by tonic GABA currents in striatopallidal MSNs will affect motor behavior and whether the increased spontaneous locomotor activity in a strain of $\alpha 5$ subunit mutant mice (Hauser et al., 2005) is mediated by a reduction in striatopallidal activity.

Together, our results suggest that $\mathrm{D}_{2}{ }^{+} \mathrm{MSN}$ have higher expression of tonic $\mathrm{GABA}_{\mathrm{A}}$ receptors containing the $\alpha 5$ subunit than $\mathrm{D}_{1}{ }^{+}$MSNs. Because tonic inhibitory currents provide a powerful mechanism to regulate cell excitability, the $\alpha 5$ subunit may serve as a novel therapeutic target for the ameliorating motor disturbances associated with Parkinson's disease.

\section{References}

Ade KK, Lovinger DM (2007) Anandamide regulates postnatal development of long-term synaptic plasticity in the rat dorsolateral striatum. J Neurosci 27:2403-2409.

Alexi T, Borlongan CV, Faull RL, Williams CE, Clark RG, Gluckman PD, Hughes PE (2000) Neuroprotective strategies for basal ganglia degeneration: Parkinson's and Huntington's diseases. Prog Neurobiol 60:409-470.

Augood SJ, Herbison AE, Emson PC (1995) Localization of GAT-1 GABA transporter mRNA in rat striatum: cellular coexpression with GAD67 mRNA, GAD67 immunoreactivity, and parvalbumin mRNA. J Neurosci 15:865-874.

Barberis A, Mozrzymas JW, Ortinski PI, Vicini S (2007) Desensitization and binding properties determine distinct alphalbeta2gamma2 and alpha3beta2gamma2 GABA(A) receptor channel kinetic behavior. Eur J Neurosci 25:2726-2740.

Belelli D, Peden DR, Rosahl TW, Wafford KA, Lambert JJ (2005) Extrasynaptic $\mathrm{GABA}_{\mathrm{A}}$ receptors of thalamocortical neurons: a molecular target for hypnotics. J Neurosci 25:11513-11520.

Blackwell KT, Czubayko U, Plenz D (2003) Quantitative estimate of synaptic inputs to striatal neurons during up and down states in vitro. J Neurosci 23:9123-9132.

Brickley SG, Cull-Candy SG, Farrant M (1996) Development of a tonic 
form of synaptic inhibition in rat cerebellar granule cells resulting from persistent activation of $\mathrm{GABA}_{\mathrm{A}}$ receptors. J Physiol (Lond) 497:753-759.

Brickley SG, Revilla V, Cull-Candy SG, Wisden W, Farrant M (2001) Adaptive regulation of neuronal excitability by a voltage-independent potassium conductance. Nature 409:88-92.

Bright DP, Aller MI, Brickley SG (2007) Synaptic release generates a tonic $\mathrm{GABA}_{\mathrm{A}}$ receptor-mediated conductance that modulates burst precision in thalamic relay neurons. J Neurosci 27:2560-2569.

Brown N, Kerby J, Bonnert TP, Whiting PJ, Wafford KA (2002) Pharmacological characterization of a novel cell line expressing human $\alpha 4 \beta 3 \delta$ $\mathrm{GABA}_{\mathrm{A}}$ receptors. Br J Pharmacol 136:965-974.

Caraiscos VB, Elliot EM, You-Ten KE, Cheng VY, Belelli D, Newell JG, Jackson MF, Lambert JJ, Rosahl TW, Wafford KA, MacDonald JF, Orser BA (2004) Tonic inhibition in mouse hippocampal CAl pyramidal neurons is mediated by alpha5 subunit-containing gamma-aminobutyric acid type A receptors. Proc Natl Acad Sci USA 101:3662-3667.

Cope DW, Hughes SW, CrunelliV (2005) GABA $_{\mathrm{A}}$ receptor-mediated tonic inhibition in thalamic neurons. J Neurosci 25:11553-11563.

Day M, Wang Z, Ding J, An X, Ingham C, Shering A, Wokosin D, Ilijic E, Sun Z, Sampson A, Mugnaini E, Deutch A, Sesack S, Arbuthnott G, Surmeier DJ (2006) Selective elimination of glutamatergic synapses on striatopallidal neurons in Parkinson's disease models. Nat Neurosci 9:251-259.

Ebert B, Thompson SA, Saounatsou K, McKernan R, Krogsgaard-Larsen P, Wafford KA (1997) Differences in agonist/antagonist binding affinity and receptor transduction using recombinant human gammaaminobutyric acid type A receptors. Mol Pharmacol 52:1150-1156.

Farrant M, Nusser Z (2005) Variations on an inhibitory theme: phasic and tonic activation of $\mathrm{GABA}_{\mathrm{A}}$ receptors. Nat Rev Neurosci 6:215-229.

Filion M, Tremblay L (1991) Abnormal spontaneous activity of the globus pallidus neurons in monkeys with MPTP-induced Parkinsonism. Brain Res 547:142-151.

Fisher JL, Macdonald RL (1997) Single channel properties of recombinant $\mathrm{GABA}_{\mathrm{A}}$ receptors containing $\gamma 2$ or $\delta$ subtypes expressed with $\alpha 1$ and $\beta 3$ subtypes in mouse L929 cells. J Physiol (Lond) 505:283-297.

Flores-Hernandez J, Hernandez S, Snyder GL, Yan Z, Fienberg A, Moss JM, Greengard P, Surmeier JD (2000) D1 dopamine receptor activation reduces $\mathrm{GABA}_{\mathrm{A}}$ receptor currents in neostriatal neurons through a PKA/ DARPP-32/PP1 signaling cascade. J Physiol (Lond) 83:2996-3004.

Fritschy JM, Brunig I (2004) Formation and plasticity of GABAergic synapses: physiological mechanisms and pathophysiological implications. Pharmacol Ther 98:299-323.

Fritschy JM, Mohler H (1995) $\mathrm{GABA}_{\mathrm{A}}$-receptor heterogeneity in the adult rat brain: differential regional and cellular distribution of seven major subunits. J Comp Neurol 359:154-194.

Gerfen CR, Engber TM, Mahan LC, Susel Z, Chase TN, Monsma Jr FJ, Sibley DR (1990) D1 and D2 dopamine receptor-regulated gene expression of striatonigral and striatopallidal neurons. Science 250:1429-1432.

Glykys J, Mody I (2007) The main source of ambient GABA responsible for tonic inhibition in the mouse hippocampus. J Physiol (Lond) 582:1163-1178.

Glykys J, Peng Z, Chandra D, Homanics G, Houser C, Mody I (2007) A new naturally occurring GABAA receptor subunit partnership with high sensitivity to ethanol. Nat Neurosci 10:40-48.

Goldstein PA, Elsen FP, Ying SW, Ferguson C, Homanics GE, Harrison NL (2002) Prolongation of hippocampal miniature inhibitory postsynaptic currents in mice lacking the $\mathrm{GABA}_{\mathrm{A}}$ receptor $\alpha 1$ subunit. J Neurophysiol 88:3208-3217.

Gong S, Zheng C, Doughty ML, Losos K, Didkovsky N, Schambra UB, Nowak NJ, Joyner A, Leblanc G, Hatten ME, Heintz N (2003) A gene expression atlas of the central nervous system based on bacterial artificial chromosomes. Nature 425:917-925.

Graybiel AM (2005) The basal ganglia: learning new tricks and loving it. Curr Opin Neurobiol 15:638-644.

Hauser J, Rudolph U, Keist R, Möhler H, Feldon J, Yee BK (2005) Hippocampal $\alpha 5$ subunit-containing $\mathrm{GABA}_{\mathrm{A}}$ receptors modulate the expression of prepulse inhibition. Mol Psychiatry 10:201-207.

Hevers W, Luddens H (2002) Pharmacological heterogeneity of gammaaminobutyric acid receptors during development suggests distinct classes of rat cerebellar granule cells in situ. Neuropharmacology 42:34-47.

Ing T, Poulter MO (2007) Diversity of $\mathrm{GABA}_{\mathrm{A}}$ receptor synaptic currents on individual pyramidal cortical neurons. Eur J Neurosci 25:723-734.

Jia F, Pignataro L, Schofield CM, Yue M, Harrison NL, Goldstein PA (2005)
An extrasynaptic $\mathrm{GABA}_{\mathrm{A}}$ receptor mediates tonic inhibition in thalamic VB neurons. J Neurophysiol 94:4491-4501.

Johnson SW, Seutin V (1997) Bicuculline methiodide potentiates NMDAdependent burst firing in rat dopamine neurons by blocking apaminsensitive $\mathrm{Ca}^{2+}$ activated $\mathrm{K}^{+}$currents. Neurosci Lett 231:13-16.

Jonas P, Bischofberger J, Sandküler J (1998) Corelease of two fast neurotransmitters at a central synapse. Science 281:419-424.

Kawaguchi Y, Wilson CJ, Emson PC (1989) Intracellular recording of identified neostriatal patch and matrix spiny cells in a slice preparation preserving cortical inputs. J Neurophysiol 62:1052-1068.

Kawaguchi Y, Wilson CJ, Augood SJ, Emson PC (1995) Striatal interneurons: chemical physiological and morphological characterization. Trends Neurosci 18:527-535.

Kita T, Kita H, Kitai ST (1984) Passive electrical membrane properties of rat neostriatal neurons in an in vitro slice preparation. Brain Res 300:129-139.

Koos T, Tepper JM, Wilson CJ (2004) Comparison of IPSCs evoked by spiny and fast-spiking neurons in the neostriatum. J Neurosci 24:7916-7922.

Kreitzer AC, Malenka RC (2007) Endocannabinoid-mediated rescue of striatal LTD and motor deficits in Parkinson's disease models. Nature 445:643-647.

Le Moine C, Normand E, Bloch B (1991) Phenotypical characterization of the rat striatal neurons expressing the D1 dopamine receptor gene. Proc Natl Acad Sci USA 88:4205-4209.

Lüscher B, Keller CA (2004) Regulation of $\mathrm{GABA}_{\mathrm{A}}$ receptor trafficking, channel activity, and functional plasticity of inhibitory synapses. Pharmacol Ther 102:195-221.

Macdonald RL, Olsen RW (1994) $\mathrm{GABA}_{\mathrm{A}}$ receptor trafficking, channel activity, and functional plasticity of inhibitory synapses. Annu Rev Neurosci 17:569-602.

Mallet N, Le Moine C, Charpier S, Gonon F (2005) Feedforward inhibition of projection neurons by fast-spiking GABA interneurons in the rat striatum in vivo. J Neurosci 25:3857-3869.

Mallet N, Ballion B, Le Moine C, Gonon F (2006) Cortical inputs and GABA interneurons imbalance projection neurons in the striatum of parkinsonian rats. J Neurosci 26:3875-3884.

Mercuri NB, Calabresi P, Stefani A, Stratta F, Bernardi G (1991) GABA depolarizes neurons in the rat striatum: an in vivo study. Synapse 8:38-40.

Mody I, Pearce RA (2004) Diversity of inhibitory neurotransmission through $\mathrm{GABA}_{\mathrm{A}}$ receptors. Trends Neurosci 27:569-575.

Mortensen M, Smart TG (2006) Extrasynaptic $\alpha \beta$ subunit $\mathrm{GABA}_{\mathrm{A}}$ receptors on rat hippocampal pyramidal neurons. J Physiol (Lond) 577:841-856.

Murase K, Ryu PD, Randic M (1989) Excitatory and inhibitory amino acids and peptide-induced responses in acutely isolated rat spinal dorsal horn neurons. Neurosci Lett 103:56-63.

Ortinski PI, Lu C, Takagaki K, Fu Z, Vicini S (2004) Regulation of inhibitory postsynaptic currents in cultured cerebellar neurons by $\mathrm{GABA}_{\mathrm{A}}$ receptor $\alpha$ subunits. J Neurophysiol 92:1718-1727.

Ortinski PI, Turner JR, Barberis A, Motamedi G, Yasuda RP, Wolfe BB, Kellar KJ, Vicini S (2006) Deletion of the $\mathrm{GABA}_{\mathrm{A}}$ receptor $\alpha 1$ subunit increases tonic $\mathrm{GABA}_{\mathrm{A}}$ receptor current: a role for GABA uptake transporters. J Neurosci 26:9323-9331.

Pacheco-Cano MT, Bargas J, Hernandez-Lopez S, Tapia D, Galarraga E (1996) Inhibitory action of dopamine involves a subthreshold $\mathrm{Cs}^{+}{ }_{-}$ sensitive conductance in neostriatal neurons. Exp Brain Res 110:205-211.

Park JB, Skalska S, Stern JE (2006) Characterization of a novel tonic gammaaminobutyric acid $_{\mathrm{A}}$ receptor-mediated inhibition in magnocellular neurosecretory neurons and its modulation by glia. Endocrinology 147:3746-3760.

Pirker S, Schwarzer C, Wieselthaler A, Sieghart W, Sperk G (2000) GABA receptors: immunocytochemical distribution of 13 subunits in the adult rat brain. Neuroscience 101:815-850.

Pouille F, Scanziani M (2001) Enforcement of temporal fidelity in pyramidal cells by somatic feed-forward inhibition. Science 293:1159-1163.

Quirk K, Blurton P, Fletcher S, Leeson P, Tang F, Mellilo D, Ragan CI, McKernan RM (1996) $\left[{ }^{3} \mathrm{H}\right] \mathrm{L}-655,708$, a novel ligand selective for the benzodiazepine site of $\mathrm{GABA}_{\mathrm{A}}$ receptors which contain the $\alpha 5$ subunit. Neuropharmacology 35:1331-1335.

Raz A, Vaadia E, Bergman H (2000) Firing patterns and correlations of 
spontaneous discharge of pallidal neurons in the normal and the tremulous 1-methyl-4-phenyl-1,2,3,6-tetrahydropyridine vervet model of parkinsonism. J Neurosci 20:8559-8571.

Richerson GB (2004) Looking for GABA in all the wrong places: the relevance of extrasynaptic $\mathrm{GABA}_{\mathrm{A}}$ receptors to epilepsy. Epilepsy Curr 4:239-242.

Rossi DJ, Hamann M, Attwell D (2003) Multiple modes of GABAergic inhibition of rat cerebellar granule cells. J Physiol (Lond) 548:97-110.

Schwarzer C, Berresheim U, Pirker S, Wieselthaler A, Fuchs K, Sieghart W, Sperk G (2001) Distribution of the major gamma-aminobutyric acid receptor subunits in the basal ganglia and associated limbic brain areas of the adult rat. J Comp Neurol 443:526-549.

Scimemi A, Semyanov A, Sperk G, Kullman D, Walker M (2005) Multiple and plastic receptors mediate tonic $\mathrm{GABA}_{\mathrm{A}}$ receptor currents in the hippocampus. J Neurosci 15:10016-10024.

Semyanov A, Walker MC, Kullmann DM (2003) GABA uptake regulates cortical excitability via cell type-specific tonic inhibition. Nat Neurosci 6:484-490.

Shen W, Hamilton SE, Nathanson NM, Surmeier DJ (2005) Cholinergic suppression of KCNQ channel currents enhances excitability of striatal medium spiny neurons. J Neurosci 25:7449-7458.

Sigworth FJ, Sine SM (1987) Data transformations for improved display and fitting of single-channel dwell time histograms. Biophys J 52:1047-1054.

Spruston N, Jaffe DB, Williams SH, Johnston D (1993) Voltage- and spaceclamp errors associated with the measurement of electrotonically remote synaptic events. J Neurophysiol 70:781-802.

Stell BM, Mody I (2002) Receptors with different affinities mediate phasic and tonic $\mathrm{GABA}_{\mathrm{A}}$ conductances in hippocampal neurons. J Neurosci 22:RC223(1-5).

Storustovu SI, Ebert B (2006) Pharmacological characterization of agonists at $\delta$-containing $\mathrm{GABA}_{\mathrm{A}}$ receptors: functional selectivity for extrasynaptic receptors is dependent on the absence of $\gamma 2$. J Pharmacol Exp Ther 316:1351-1359.

Tepper JM, Koos T, Wilson CJ (2004) GABAergic microcircuits in the neostriatum. Trends Neurosci 27:662-669.
Venance L, Glowinski J (2003) Heterogeneity of spike frequency adaptation among medium spiny neurones from the rat striatum. Neuroscience 122:77-92.

Verheugen JA, Fricker D, Miles R (1999) Noninvasive measurements of the membrane potential and GABAergic action in hippocampal interneurons. J Neurosci 19:2546-2555.

Verdoorn TA, Draguhn A, Ymer S, Seeburg PH, Sakmann B (1990) Functional properties of recombinant rat $\mathrm{GABA}_{\mathrm{A}}$ receptors depend upon subunit composition. Neuron 4:919-928.

Vicini S, Ortinski PI (2004) Genetic manipulations of GABAA receptor in mice make inhibition exciting J Pharmacol Exp Ther 103:109-120.

Vicini S, Ferguson C, Prybylowski K, Kralic J, Morrow AL, Homanics GE (2001) $\mathrm{GABA}_{\mathrm{A}}$ receptor $\alpha 1$ subunit deletion prevents developmental changes of inhibitory synaptic currents in cerebellar neurons. J Neurosci 21:3009-3016.

Wall MJ, Usowicz MM (1997) Development of action potential-dependent and independent spontaneous GABAA receptor-mediated currents in granule cells of postnatal rat cerebellum. Eur J Neurosci 9:533-548.

Wang ZL, Day M, Ronesi J, Yin HH, Ding J, Tkatch T, Lovinger DM, Surmeier DJ (2006) Dopaminergic control of corticostriatal long-term synaptic depression in medium spiny neurons is mediated by cholinergic interneurons. Neuron 50:443-452.

Wei W, Zhang N, Peng Z, Houser CR, Mody I (2003) Perisynaptic localization of $\delta$ subunit containing $\mathrm{GABA}_{\mathrm{A}}$ receptors and their activation by GABA spillover in the mouse dentate gyrus. J Neurosci 23:10650-10661.

Wolf JA, Moyer JT, Lazarewicz MT, Contreras D, Benoit-Marand M, O’Donnell P, Finkel LH (2005) NMDA/AMPA ratio impacts state transitions and entrainment to oscillations in a computational model of the nucleus accumbens medium spiny projection neuron. J Neurosci 25:9080-9095.

Wu Y, Wang W, Richerson GB (2006) The transmembrane sodium gradient influences ambient GABA concentration by altering the equilibrium of GABA transporters. J Neurophysiol 96:2425-2436.

Yamada J, Furkawa T, Ueno S, Ymamoto S, Fukada A (2007) Molecular basis for the $\mathrm{GABA}_{\mathrm{A}}$ receptor-mediated tonic inhibition in rat somatosensory cortex. Cereb Cortex 17:1782-1787. 